\title{
Advances and problems in hydrocarbon exploration in the Tazhong area, Tarim Basin
}

\author{
Zhou Xinyuan ${ }^{1}$, Pang Xiongqi ${ }^{2,3 *}$, Li Qiming ${ }^{1}$, Pang Hong, ${ }^{2,3}$ Xiang Caifu ${ }^{2,3}$, \\ Jiang Zhenxue ${ }^{2,3}$, Li Sumei ${ }^{2,3}$ and Liu Luofu ${ }^{2,3}$ \\ ${ }^{1}$ Tarim Oilfield Company, PetroChina, Korla, Xinjiang 841000, China \\ ${ }^{2}$ Basin and Reservoir Research Center, China University of Petroleum, Beijing 102249, China \\ ${ }^{3}$ State Key Laboratory of Petroleum Resources and Prospecting, Beijing 102249, China \\ (C) China University of Petroleum (Beijing) and Springer-Verlag Berlin Heidelberg 2010
}

\begin{abstract}
Located in the middle of the Tarim Basin, Tazhong is a typical area of compound reservoirs rich in oil and gas found in the Carboniferous, Silurian and Ordovician strata. The proved, probable and possible reserves (3P reserves) in the area amount to $5 \times 10^{8}$ tons, so it is of great significance to study the advances and problems in hydrocarbon exploration in the Tazhong area. On the basis of exploration history and analysis of scientific problems, we outline eight achievements: distribution characteristics of reservoirs, stages of reservoir formation, different sources of oil and gas and their respective contributions, the effective regional caprock and reservoir-caprock combinations dominating the vertical distribution of hydrocarbon reservoirs, the control of the Tazhong Palaeo-uplift on reservoir formation and establishing geologic models, structure balance belts influencing the reconstruction and residual potential of reservoirs after accumulation, the rules and mechanisms of fractures controlling oil and gas, and the types of favorable reservoirs and their characteristics of controlling oil and gas distribution. We further point out the main problems about the oil and gas exploration in the Tazhong area and put forward some relevant proposals.
\end{abstract}

Key words: Tarim Basin, petroleum geology and exploration, controlling factors of hydrocarbon accumulation, rules of hydrocarbon accumulation

\section{Introduction}

The Tazhong area, located in the middle of the Tarim Basin, is an inherited palaeo-uplift. It is adjacent to the Manjiaer Sag in the north, the Tangguzibasi Sag in the south, the Tadong low uplift in the east, and the Bachu low uplift in the west, and has an area of 22,000 $\mathrm{km}^{2}$ for hydrocarbon exploration (Fig. 1). Exploration results have proved that this area has very good conditions for reservoir formation (Zhai and Wang, 1999; Wu et al, 2002; Yang et al, 2007a; 2007d; Zhou et al, 2006; 2009; Lü et al, 2007). It can be divided into Tazhong No.1 slope break belt, Tazhong No.10 structural belt, Tazhong major horst belt, whose structural positions rise gradually, and Tazhong No.1-8 buried hill belt. Over 120 wells have been drilled so far, and more than 50 wells have produced commercial oil or gas. Large reservoirs have been found in Tazhong4, Tazhong16, Tazhong45, Tazhong24Tazhong26, Tazhong83, and Tazhong62-Tazhong82 (Yang et al, 2007c; Han et al, 2007). Major breakthroughs made in 2007 in the exploration of the weathering crust in the buried hills of the underlying structural layer indicated a

*Corresponding author. email: pangxq@cup.edu.cn

Received September 2, 2009 very bright future and great potentials in the area. Therefore, it is of vital significance to review the exploration history and achievements and to discuss the directions of further exploration in the Tazhong area.

\section{Exploration history and problems in the Tazhong Uplift}

\subsection{Five stages of hydrocarbon exploration in the Tazhong Uplift}

Hydrocarbon exploration in Tazhong began in 1983 and 14 reservoirs have been found in the Carboniferous, Silurian and Ordovician, with $3 \mathrm{P}$ reserves amounting to $5 \times 10^{8}$ tons. The exploration history in Tazhong can be divided into five stages (Fig. 2), according to the drilling of key wells.

1983-1990, the stage of exploring the Tazhong1 carbonate buried hill traps. In 1983, the former China Ministry of Petroleum Industry set up a Sino-US desert seismic team to launch a fight against the "Sea of Death". The Tazhong1 well was drilled on May 5, 1989 and on October 19, productive commercial condensate gas flow was obtained on the top of the Cambrian buried hill, which started the exploration in the whole area.

1991-1997, the stage of exploring the Carboniferous, 


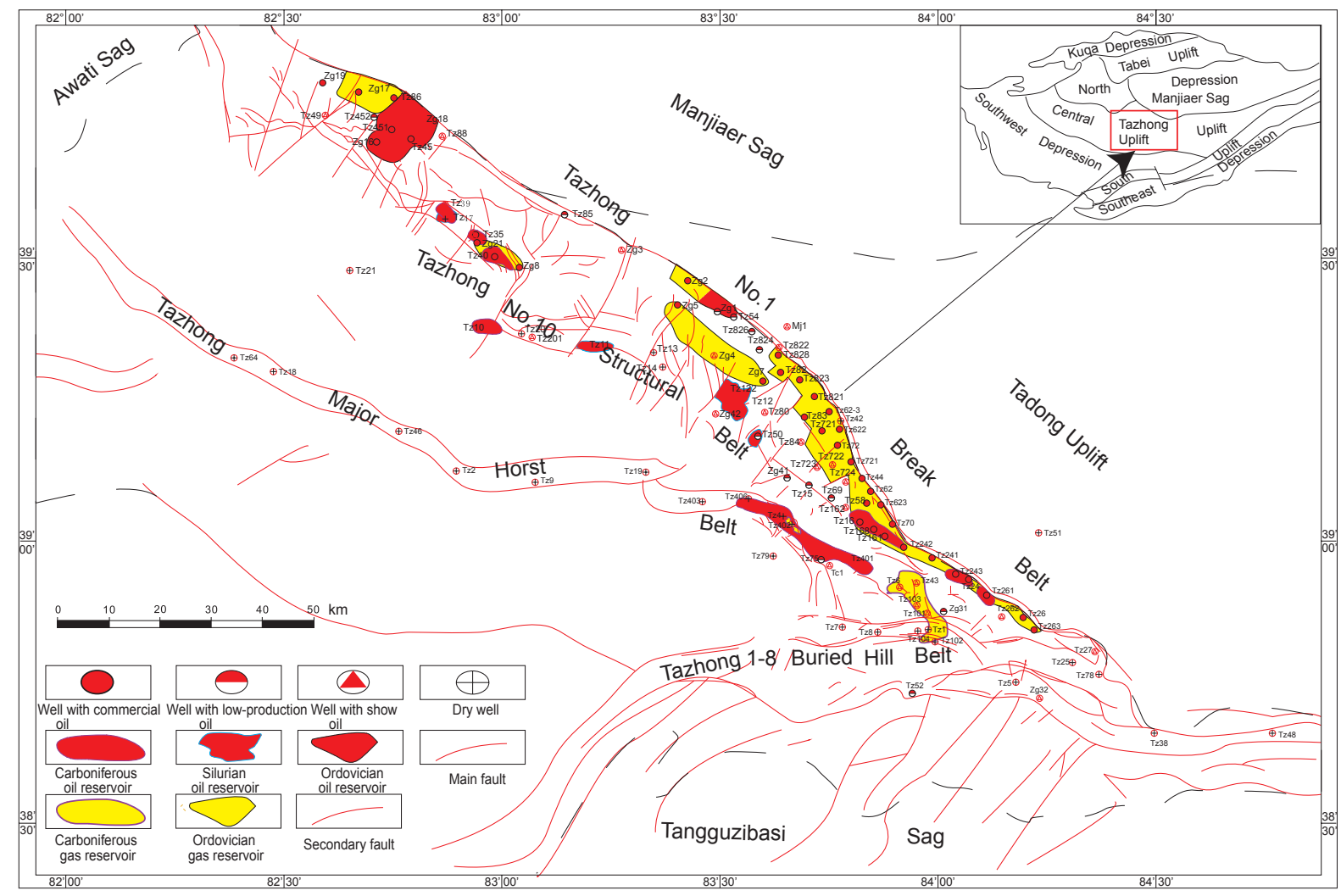

Fig. 1 Geologic structures and petroleum reservoirs in the Tazhong area

Silurian and Ordovician structural traps. In 1992, the drilling of Tazhong4 well obtained productive commercial oil flows and the Tazhong4 oilfield was found. Based on the idea of looking for oil in the low structural traps, seven Donghe sandstone oilfields were found, such as Tazhong10 and Tazhong16. Guided by the idea of "exploring the Carboniferous as the main target and exploring the Silurian meanwhile", the Tazhong11 well was drilled in 1994, which was the first commercial oil well in the Silurian. The discovery of commercial flows in the Ordovician carbonate in the Tazhong24 well drilled in 1996 provided an understanding of the control of fault belts and structures on oil and gas. Also in 1996, the discovery of commercial flows in the Upper Ordovician limestone section in the Tazhong26, Tazhong44, and Tazhong45 wells made people realize that the Tazhong1 fault belt is favorable for hydrocarbon accumulation.
1998-2002, the stage of stagnation. After discovering in 1997 that the Tazhong1 fault belt is favorable for hydrocarbon accumulation, the exploration achieved little progress. After 1998, the workload and area of exploration quickly reduced. The main reasons may be the small size and strong activity of the Tazhong Palaeo-uplift, complicated reservoir formation and distribution, deep burial depth of the target strata, and the difficulty of exploration.

2003-2005, the stage of exploring lithologic reservoirs in the Silurian and the reef flat body in the Tazhong No.1 slope break belt. With the technological advancements and rearrangement of 3D seismic exploration, structural-lithologic reservoirs in Tazhong12 and Tazhong50 wells and lithologic reservoirs in Tazhong62 and Tazhong169 wells were found in 2003 through reexamination of existing wells. Accordingly, the guideline for the exploration of the Silurian strata changed

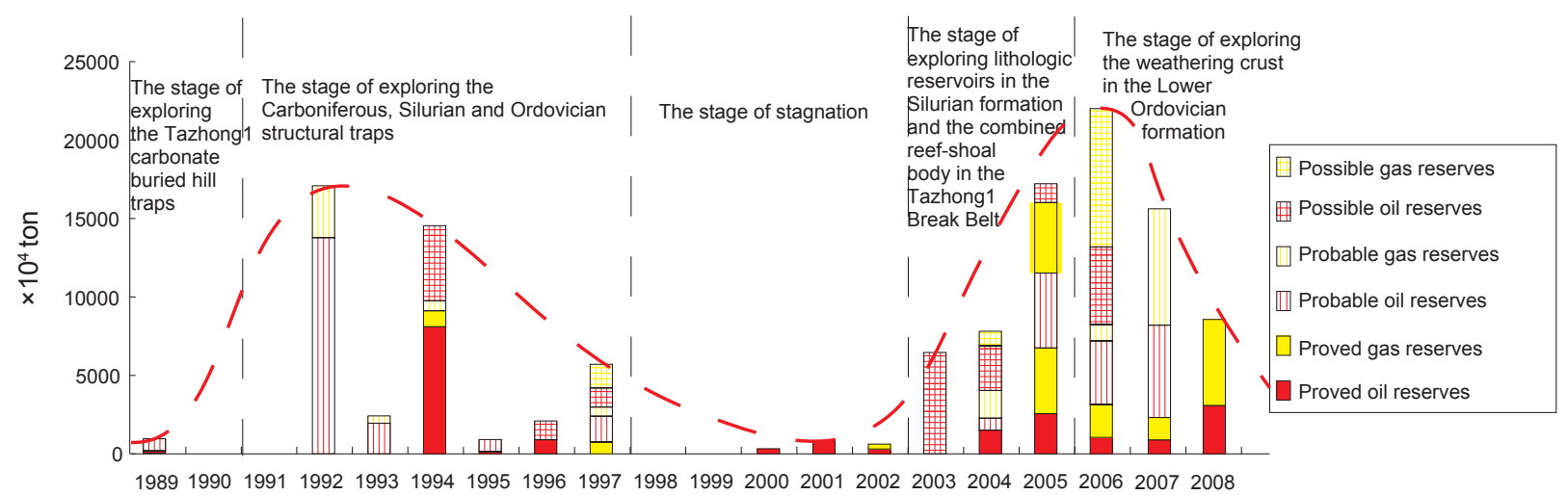

Fig. 2 Changes in reserves and stages of exploration in the Tazhong area 
from looking for structural reservoirs to looking for lithologic reservoirs in broader areas, and from assuming that most of the Silurian strata were damaged to believing that they have a great potential for oil and gas. Rethinking of the Tazhong No.1 slope break belt also brought three changes: looking for oil from along fault zones to along slope break zones, from assuming that faults control oil to believing that platform edges control oil, and from assuming that local structures control oil to believing that the whole reservoir bed controls oil. These new viewpoints indicate that the Tazhong No.1 slope break belt may be a large oil-gas field.

2006-present, the stage of exploring the weathering crust in the Lower Ordovician strata. Believing that the carbonate strata are favorable for the formation of complicated reservoirs, the reservoirs in the Lower Ordovician weathering crust were explored in 2006. Breakthroughs were made in Tazhong83 and Tazhong721 wells, which opened a fresh field in carbonate exploration.

\subsection{Three main geological problems of hydrocarbon exploration in the Tazhong Uplift}

The unknown hydrocarbon distribution characteristics and controlling factors are the main geological problems in the Tazhong area. The focus in production is mainly on drilling but not on the hydrocarbon distribution and accumulation rules. The main problems in hydrocarbon exploration in the Tazhong Uplift can be summarized in three aspects:

1) The relative contribution amounts of mixed sources are unclear. There are three kinds of research results in the hydrocarbon sources in the Tazhong Uplift. Some scholars believed that the hydrocarbon mainly came from the Cambrian, some scholars believed that the hydrocarbon mainly came from the Ordovician, and some scholars believed that the hydrocarbon is a mixture of the two sources, but the mixed ratio is unknown. It is difficult to determine the exploration direction without clear hydrocarbon sources.

2) Hydrocarbon accumulation periods are unclear. Multistage hydrocarbon accumulation in the Tazhong Uplift is the consensus of most scholars. However, there are considerable debates about how many hydrocarbon accumulation stages exist in the Tazhong area and when they occurred.
3) The main controlling factors of hydrocarbon distribution are unclear. The distribution of oil and gas in the Tazhong area is very complicated. There are reservoirs not only formed early but also formed late, not only single source but also mixed source, and not only formed after adjustment and reconstruction but also formed recently. The formation and distribution of these complicated reservoirs are controlled by many factors, but the main controlling factors are still unclear.

In this paper, we studied the problems above and obtained some new understandings.

\section{Major advances and achievements of hydrocarbon exploration in the Tazhong area}

\subsection{Knowing the reservoir distribution}

The reservoir distribution in the Tazhong area is characterized by "blocking in the east and west, gas in the north but oil in the south, and gas in the underlying layers but oil in the overlying layers". The Carboniferous and Silurian clastic reservoirs are distributed in the eastern and western blocks separated by the NE-strike fracture associated with the NW strike-slip fault. There are more reservoirs already discovered in the east than in the west: seven in the east and five in the west (Fig. 3(a) and 3(b)). Besides, large fields like Tazhong16 and Tazhong4 are all found in the east, which means there are larger reserves in the east than in the west. For the Ordovician carbonate reservoirs, their distribution is characterized by "gas in the north but oil in the south", that is, more gas condensate reservoirs than oil reservoirs exist outside the Tazhong No.1 slope break belt while more oil reservoirs exist inside it. As to the vertical distribution in the whole Tazhong area, the feature is "gas in the underlying layers but oil in the overlying layers", that is, the underlying carbonate layers mainly contain gas pools while the overlying clastic layers mainly contain oil pools (Fig. 3).

\subsection{Determining the stages of reservoir formation}

Various research has been done on the stages of reservoir formation in Tazhong mainly using inverse modeling of inclusions (Table 1) and forward modeling of hydrocarbon

Table 1 Division of stages of the Silurian reservoir formation in the Tarim Basin

\begin{tabular}{|c|c|c|c|c|c|c|c|c|c|c|c|c|}
\hline \multirow{2}{*}{$\begin{array}{c}\text { Zhou } \\
(1997,2000)\end{array}$} & \multirow{2}{*}{$\begin{array}{c}\text { Jia et al } \\
\text { (1995) }\end{array}$} & \multirow{2}{*}{$\begin{array}{l}\text { Kang } \\
(1996)\end{array}$} & \multirow{2}{*}{$\begin{array}{c}\text { Wang } \\
(1996)\end{array}$} & \multirow{2}{*}{$\begin{array}{c}\mathrm{Li} \\
(1997)\end{array}$} & \multirow{2}{*}{$\begin{array}{l}\text { Zhou et al } \\
\text { (1997) }\end{array}$} & \multirow{2}{*}{$\begin{array}{c}\text { Kang et al } \\
(2001)\end{array}$} & \multicolumn{2}{|c|}{$\begin{array}{l}\text { Zhang et al } \\
(2000 \mathrm{~b})\end{array}$} & \multirow{2}{*}{$\begin{array}{l}\text { Liu } \\
\text { and Kang } \\
\text { (1999) }\end{array}$} & \multirow{2}{*}{$\begin{array}{l}\text { Zhang et al } \\
\quad(2002)\end{array}$} & \multirow{2}{*}{$\begin{array}{l}\text { Li et al } \\
(2002)\end{array}$} & \multirow[t]{2}{*}{ In this paper } \\
\hline & & & & & & & Tabei & Tazhong & & & & \\
\hline \multirow{2}{*}{$\begin{array}{c}\text { Recent } \\
\left(\mathrm{N}_{1} \text { to now) }\right.\end{array}$} & \multirow[b]{3}{*}{ Himalayan } & Himalayan & \multirow[b]{3}{*}{ Himalayan } & \multirow[b]{3}{*}{ Himalayan } & \multirow{3}{*}{$\frac{\text { Himalayan }}{\begin{array}{c}\text { Indosinian } \\
\text {-Yanshan }\end{array}}$} & \multirow{3}{*}{$\begin{array}{c}\text { Indosinian } \\
\text {-Early } \\
\text { Yanshan }\end{array}$} & \multirow{3}{*}{\multicolumn{2}{|c|}{$\begin{array}{l}\text { Indosinian Himalayan } \\
\text {-Himalayan }\end{array}$}} & & & & \\
\hline & & $\begin{array}{c}\text { Late } \\
\text { Yanshan }\end{array}$ & & & & & & & & & & \\
\hline $\begin{array}{c}\text { Late } \\
\left(\mathrm{J}_{3}-\mathrm{N}_{1}\right)\end{array}$ & & $\begin{array}{c}\text { Indosinian } \\
\text {-Early } \\
\text { Yanshan }\end{array}$ & & & & & & & Himalayan & i Himalayan & $\mathrm{K}-\mathrm{E}$ & Yanshan-Himalayan \\
\hline \multirow{2}{*}{$\begin{array}{l}\text { Middle } \\
(\mathrm{P}-\mathrm{T})\end{array}$} & $\begin{array}{c}\text { Late } \\
\text { Hercynian } \\
\text {-Indosinian }\end{array}$ & $\begin{array}{c}\text { Late } \\
\text { Hercynian }\end{array}$ & $\begin{array}{c}\text { Late } \\
\text { Hercynian }\end{array}$ & $\begin{array}{c}\text { Late } \\
\text { Hercynian } \\
\text {-Indosinian }\end{array}$ & $\begin{array}{c}\text { Late } \\
\text { Hercynian }\end{array}$ & $\begin{array}{c}\text { Late } \\
\text { Hercynian }\end{array}$ & & $\begin{array}{c}\text { Late } \\
\text { Hercynian }\end{array}$ & Before K & $\begin{array}{l}\text { Late } \\
\text { Hercynian }\end{array}$ & & Late Hercynian \\
\hline & $\begin{array}{c}\text { Early } \\
\text { Hercynian }\end{array}$ & $\begin{array}{c}\text { Early } \\
\text { Hercynian }\end{array}$ & $\begin{array}{c}\text { Early } \\
\text { Hercynian }\end{array}$ & $\begin{array}{c}\text { Early } \\
\text { Hercynian }\end{array}$ & $\begin{array}{c}\text { Early } \\
\text { Hercynian }\end{array}$ & & & & & \multirow{2}{*}{$\begin{array}{l}\text { Caledonian } \\
\text {-Early } \\
\text { Hercynian }\end{array}$} & & \\
\hline $\begin{array}{l}\text { Early } \\
\left(\mathrm{S}_{3}-\mathrm{D}\right)\end{array}$ & & & & & & & $\begin{array}{c}\text { Late } \\
\text { Caledonian }\end{array}$ & $\begin{array}{c}\text { Late } \\
\text { ACaledonian }\end{array}$ & $\begin{array}{c}\text { Late } \\
\text { Caledonian }\end{array}$ & & S & Late Caledonian \\
\hline
\end{tabular}




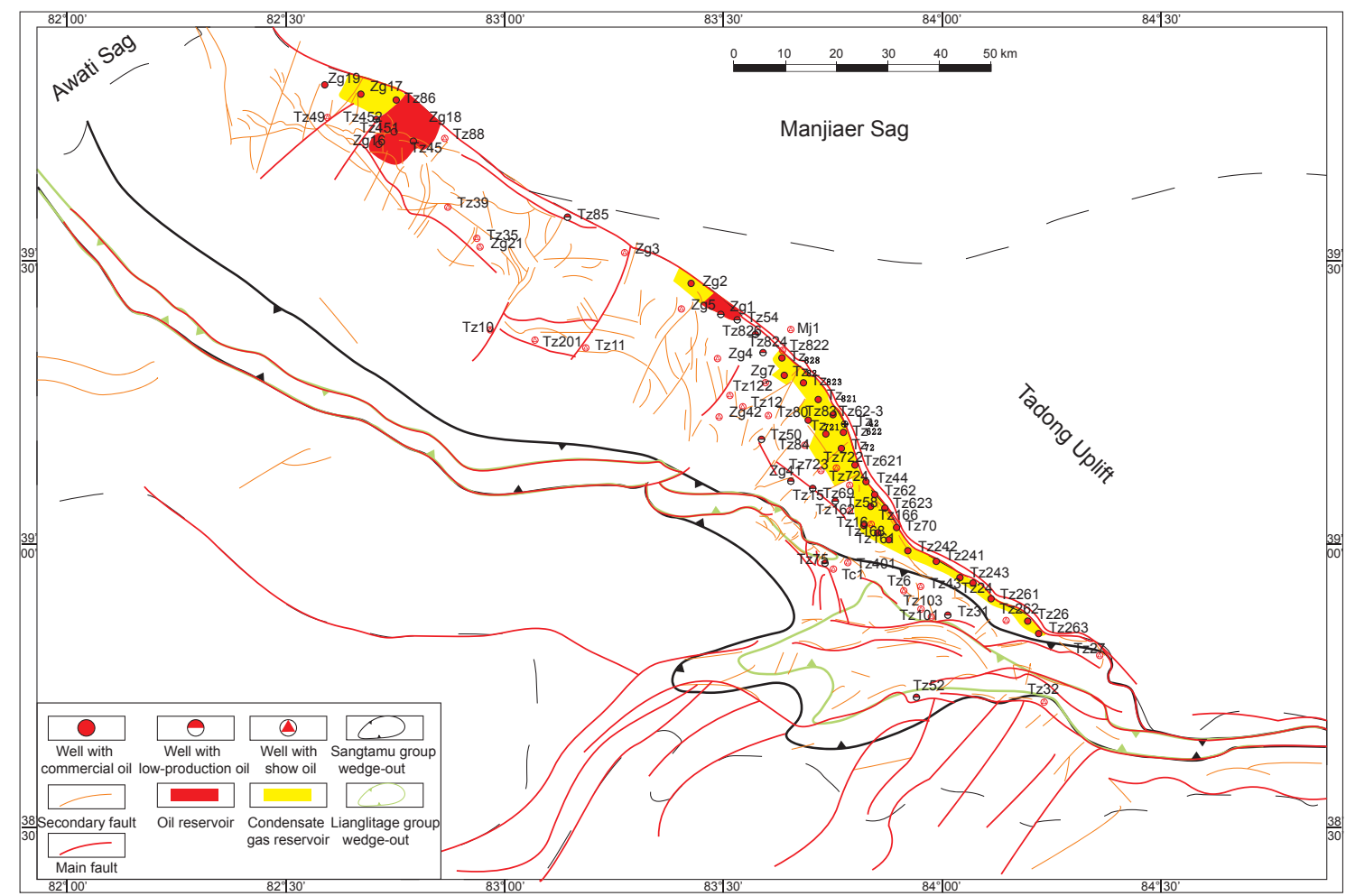

(a) Distribution of the Carboniferous reservoirs

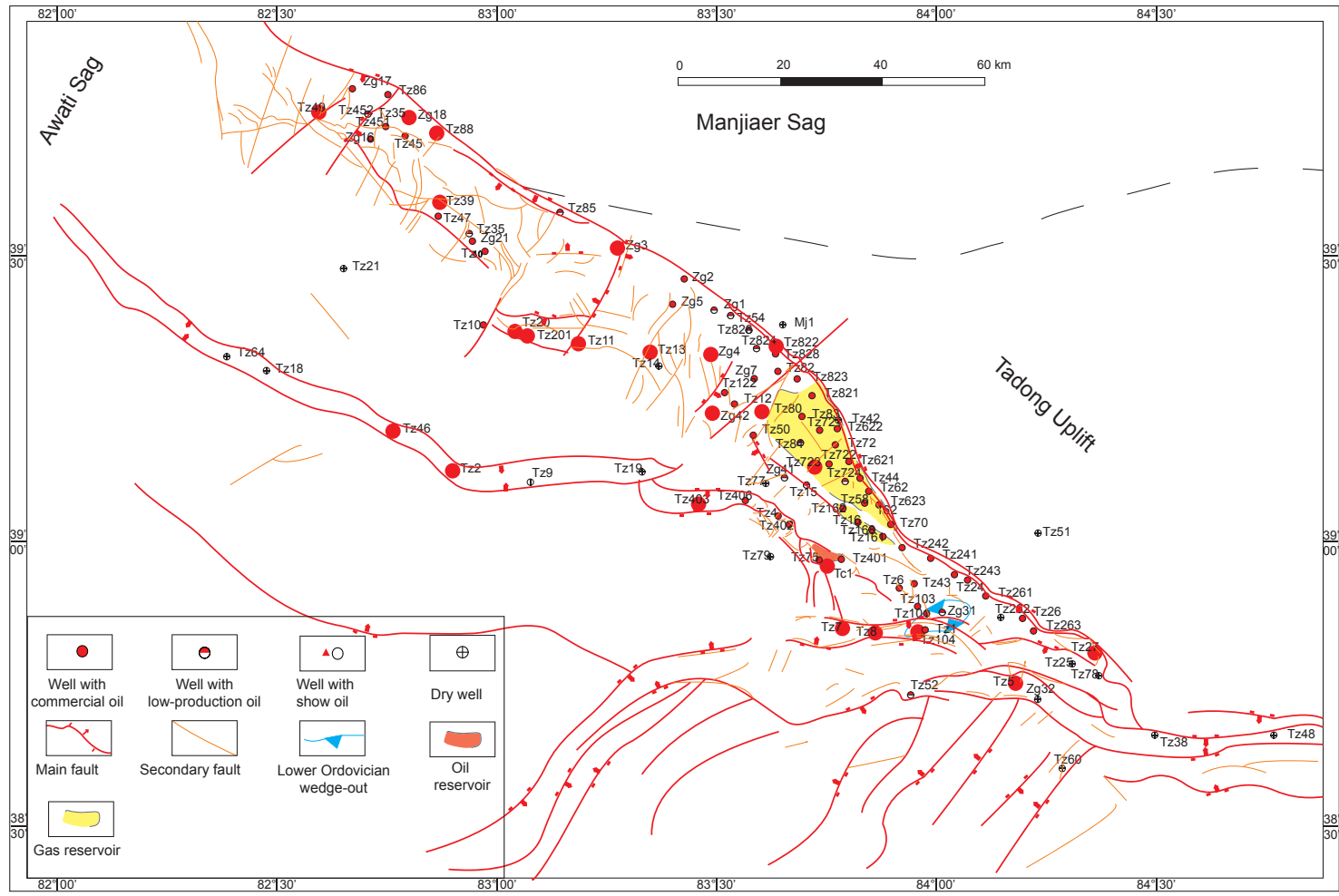

(b) Distribution of the Silurian reservoirs 


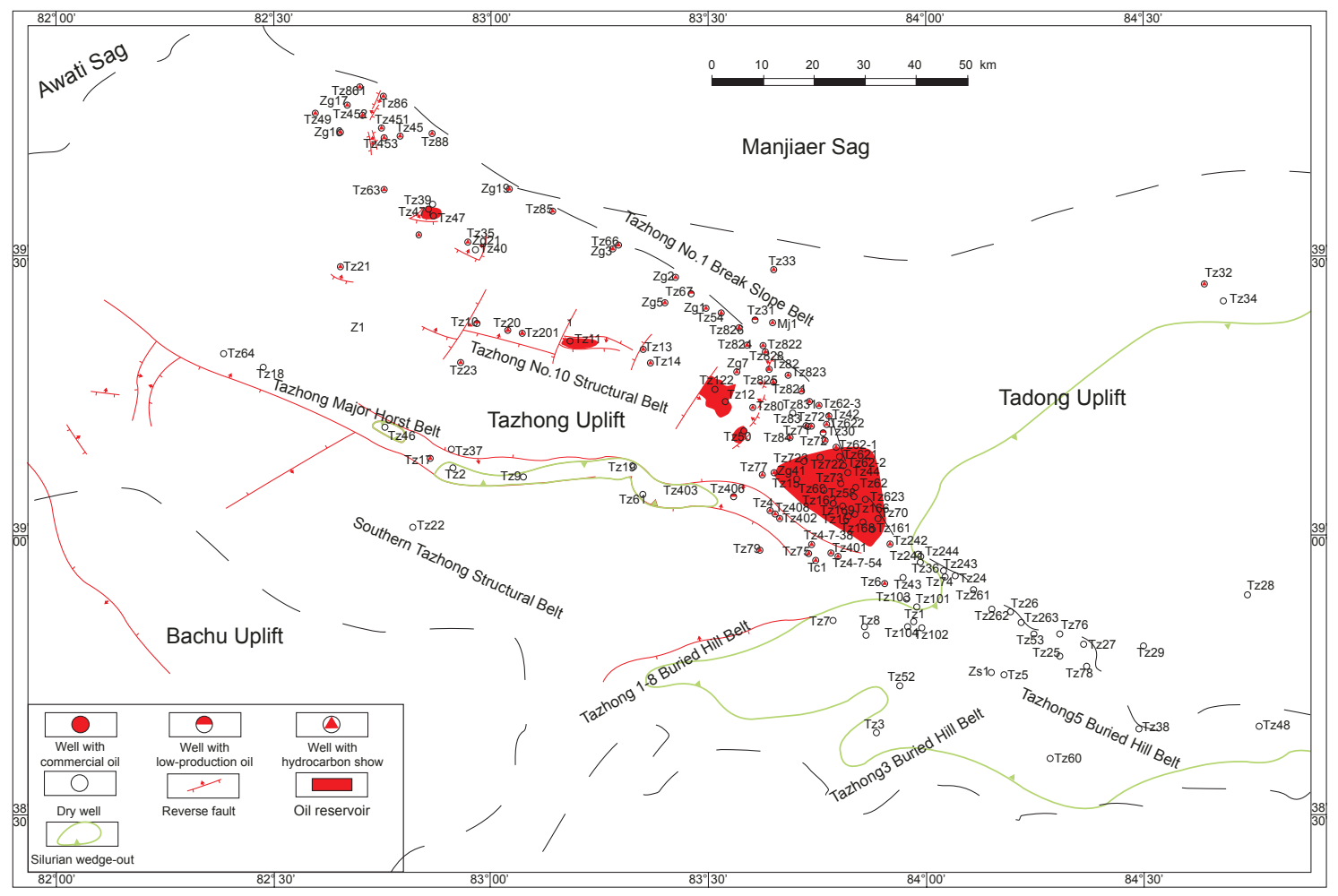

(c) Distribution of the Upper Ordovician reservoirs

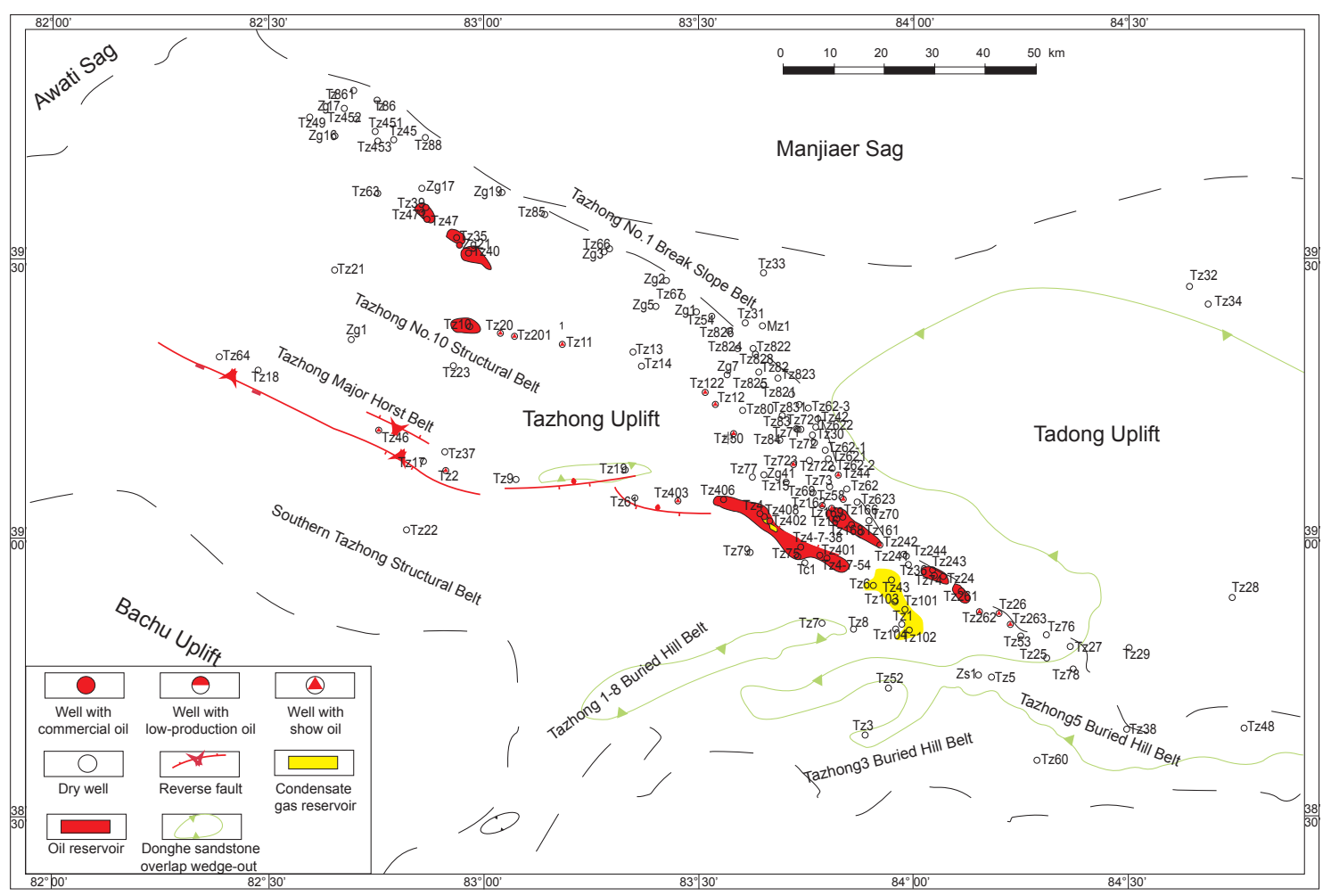

(d) Distribution of the Lower Ordovician reservoirs

Fig. 3 Distribution of reservoirs in the Tazhong Uplift 
expulsion amount (Pang et al, 2006) (Fig. 4). The results are almost the same, that is, there are four stages in the reservoir formation in the Tazhong area, including the early Caledonian, the late Caledonian, the late Hercynian and the YanshanHimalayan. It can also be proved by the different properties of oil and gas in the same target layer of the same well.

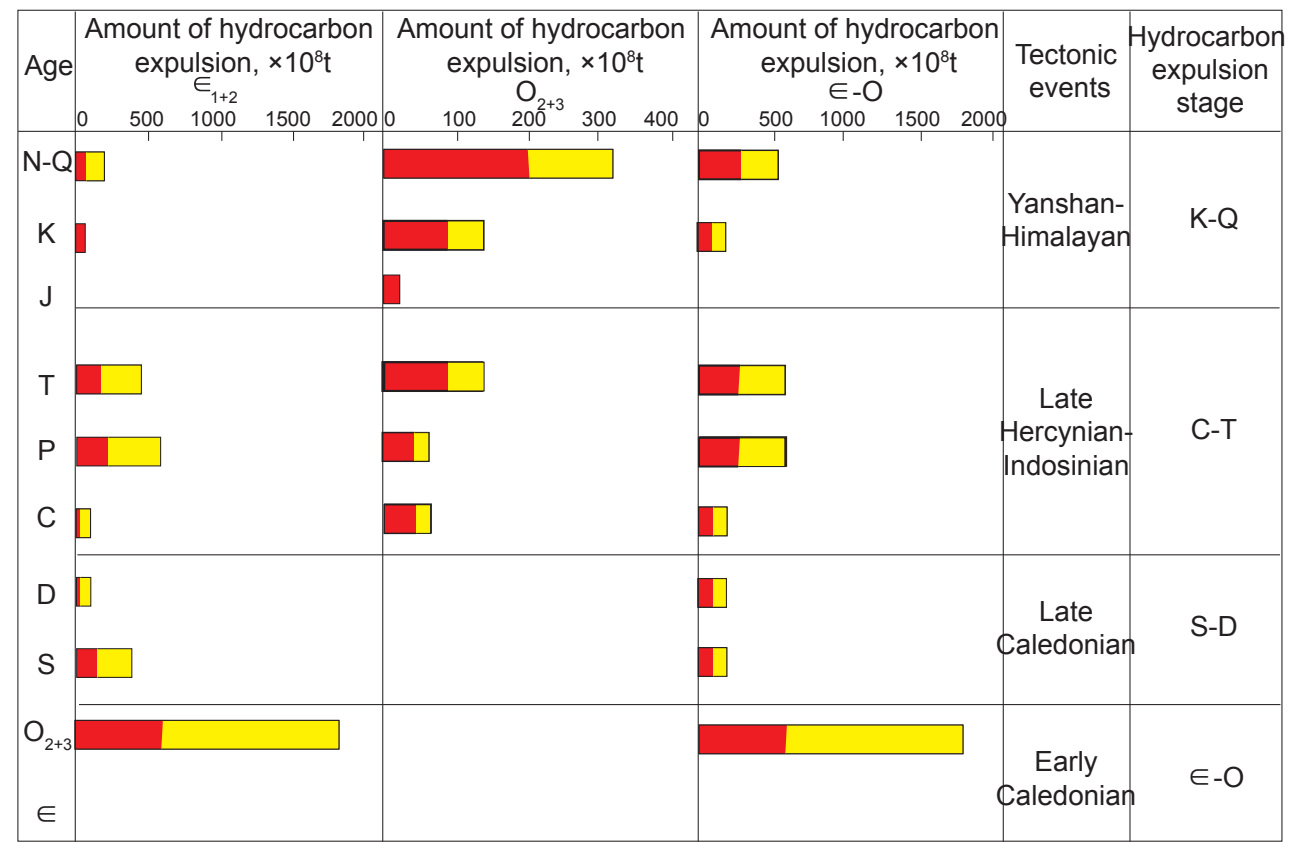

Fig. 4 Division of stages of the Middle-Lower Cambrian and the Middle-Upper Ordovician source rock formation in the Tarim Basin (Pang et al, 2006)

\subsection{Understanding the different sources of oil and gas and their respective contributions}

It has been widely acknowledged that the oil in Tazhong mainly comes from the Cambrian-Ordovician source rocks, and our study also confirms this point. However, there is a debate about which set of rocks is the main source. Zhang Shuichang and Liang Digang, based on the comparison of biomarkers (age-indicating biomarkers such as dinosteranes, triaromatic dinosteranes, and 24-norcholestanes), argued that the Ordovician crude oil mainly comes from the MiddleUpper Ordovician source rocks (Liang et al, 2000; Hanson et al, 2000; Zhang et al, 2000a; 2000b). Other researchers, through analyzing the compositions in the hydrocarbon (phenylic isoprenoid hydrocarbon, moderate molecular weight, light hydrocarbon and sulfur isotope), believed that the Cambrian-Lower Ordovician source rocks may be the main contributors (Chen et al, 2000; Zhao and Li, 2002; Cai et al, 2001; 2007; 2009; Pan and Liu, 2009).

The hydrocarbon in the Tazhong area comes from the mixed sources of Cambrian and Ordovician (Li et al, 2008), and the contribution of Cambrian source rocks is between $13 \%$ and $91 \%$. It is $100 \%$ only for individual reservoirs and decreases with increasing depth (Fig. 5). Understanding the distribution of mixed sources depends on the following two aspects: the discovery of hydrocarbon inclusions which came from a single source and the analysis technology of single hydrocarbon isotope ratios. We reexamined the geochemical indicators used in previous studies, established new geochemical identifying criteria, i.e., the single hydrocarbon isotope ratios in the inclusions from both the crude oil and the reservoirs, and improved the criteria for oil source comparison. According to our study, the crude oil in the Tazhong area comes from mixed sources of both the Cambrian-Lower Ordovician and the Middle-Upper Ordovician source rocks. We also analyzed the proportions of the contribution of these two sets of source rocks by comparing the different single hydrocarbon isotope ratios. The calculation formula is:

$$
\operatorname{Mix}\left(E_{\mathrm{ma}}\right)(\%)=\left(\delta M_{i}-\delta E_{\mathrm{mb}}\right) /\left(\delta E_{\mathrm{ma}}-\delta E_{\mathrm{mb}}\right) \times 100
$$

where, end-member oil a: TZ62 well (Silurian) crude oil (similar to the TD2 well); end-member oil b: TZ825 well (Ordovician) included hydrocarbon (similar to the YM2 well); $\operatorname{Mix}\left(E_{\mathrm{ma}}\right)$ : mixed amount of end-member oil a; $\delta M_{i}$ : isotope ratio of crude oil $i$; $\delta E_{\mathrm{ma}}$ : isotope ratio of end-member oil a; $\delta E_{\mathrm{mb}}$ : isotope ratio of end-member oil b.

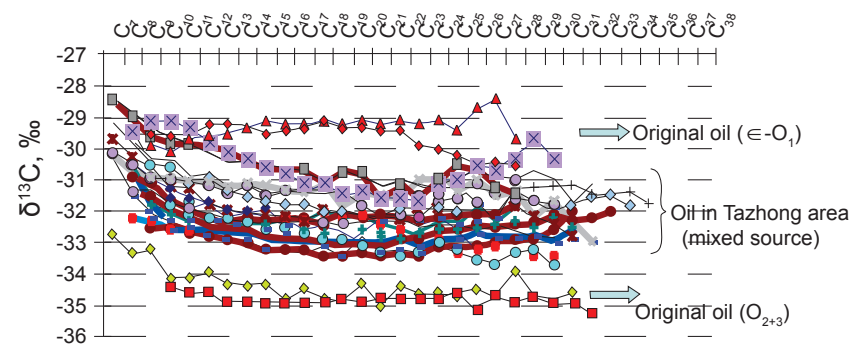

(a) The distribution of single hydrocarbon isotope in Tazhong area 


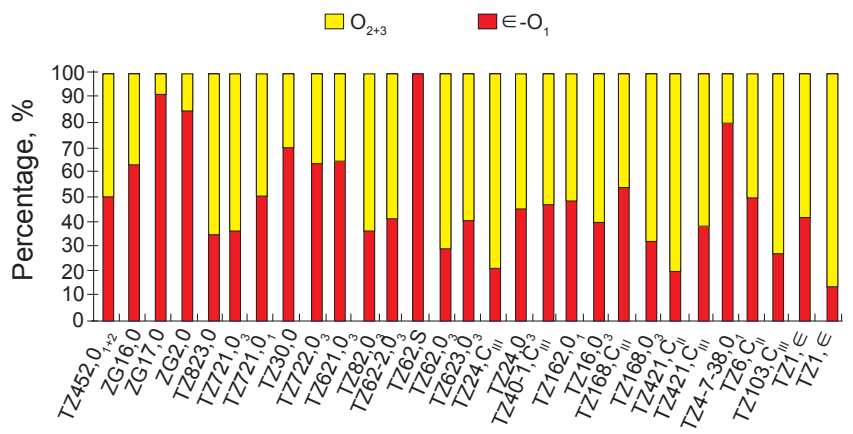

(b) The relative contribution of mixed oil in Tazhong area

Contribution of Cambrian source, \%

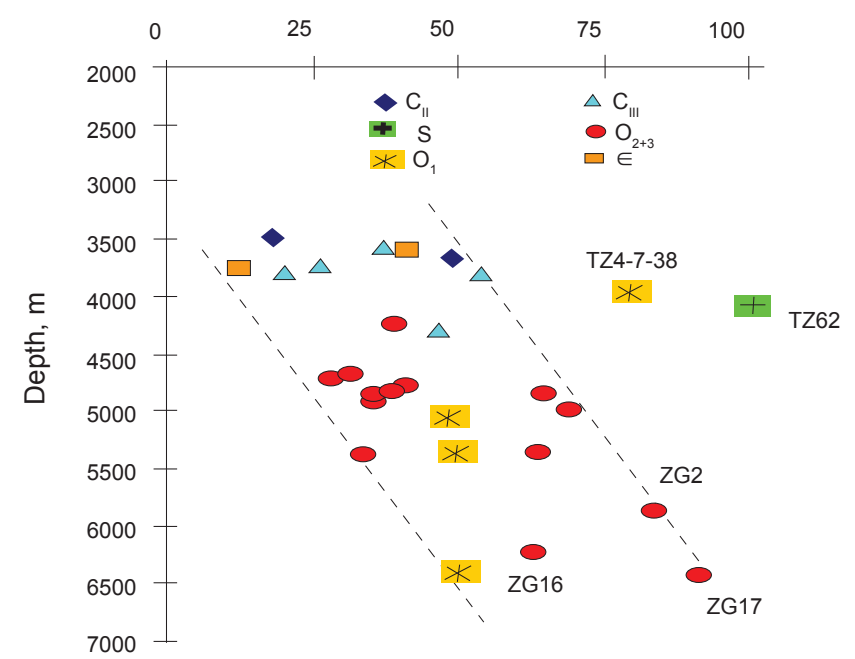

(c) The relationship between relative contribution of mixed oil and depth in Tazhong area

Fig. 5 Mixed sources of crude oil and their respective contributions in the Tazhong area (Li et al, 2008)

\subsection{Discussing the control of the Tazhong Palaeo- uplift on reservoir formation and establishing geologic models}

As an inherited palaeo-uplift, the Tazhong area serves as the most favorable area for petroleum accumulation and plays a dominant role in reservoir formation and distribution (Kang, 1992; He, 1996; Zhai and He, 2004; Wang and Zhao, 2006). Such control can be summarized in the following four aspects.

1) The Tazhong Palaeo-uplift controls the direction of hydrocarbon migration because its low potential energy attracts the oil and gas expelled from the surrounding source rocks to migrate towards the uplift under the action of buoyancy. In the process of migration, the oil and gas may accumulate into a reservoir when encountering proper traps. In general, the hydrocarbon reservoirs already discovered are mainly distributed in the palaeo-uplift in the Tazhong area (Fig. 6).

2) The Tazhong Palaeo-uplift controls the locations of reservoirs. For example, for the clastic rocks of upper structural layers (Carboniferous-Silurian), the oil and gas are located mainly in the top of the palaeo-uplift and the upper parts of slopes (e.g., the Tazhong4 oilfield). For the carbonate rocks of lower structural layers (Ordovician-Cambrian),

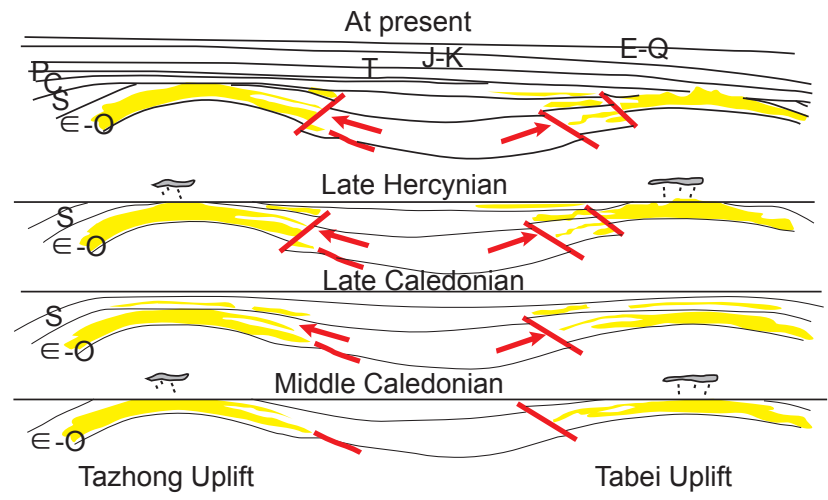

(a) Structural evolution model of Tazhong Uplift

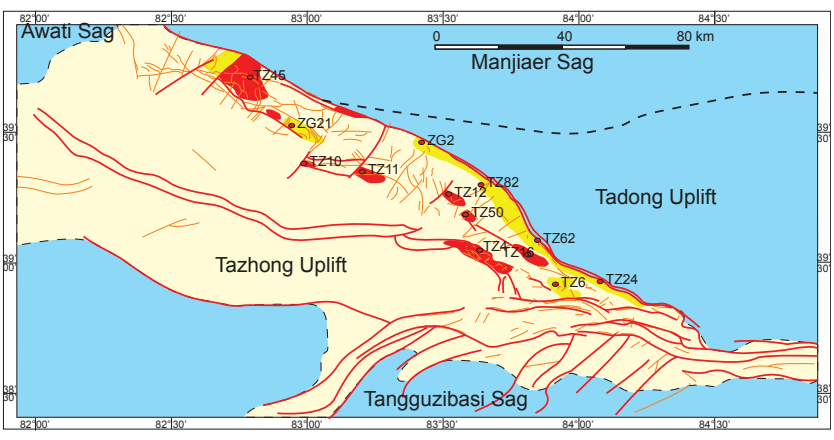

(b) Oil and gas distribution plane of Tazhong Uplift

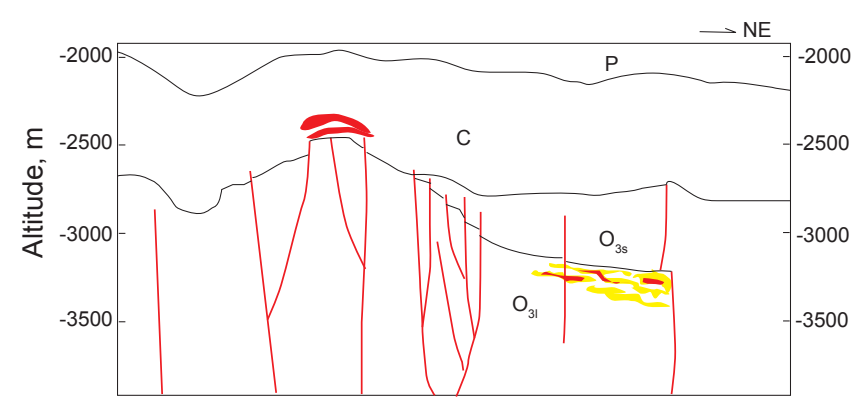

(c) Oil and gas distribution profile of Tazhong Uplift

Fig. 6 Distribution of hydrocarbon reservoirs in the Tazhong Uplift

the oil and gas are located mainly in the pericline or lower parts of slopes in the palaeo-uplift (e.g., the Tazhong No.1 condensate gas field). This is because the slopes are favorable for hydrocarbon preservation while the high positions of the palaeo-uplift are not favorable because of erosion. The above characteristics can be found in Tazhong, Tabei and Yingmaili areas (Fig. 7).

3) The Tazhong Palaeo-uplift controls the types of reservoirs. For clastic rocks, drape-anticline reservoirs are formed on the top (e.g., the Tazhong4 Carboniferous oil reservoir), pinch-out reservoirs are formed on the slopes (e.g., the Tazhong16 Carboniferous oil reservoir), and overlap reservoirs are formed in the lower parts of the western slopes (e.g., the Tazhong11 Silurian oil reservoir). For carbonate rocks, weathering crust reservoirs are formed on the top (e.g., the Tazhong1 Cambrian condensate gas reservoir), karst oil reservoirs and inner-structural condensate gas reservoirs 


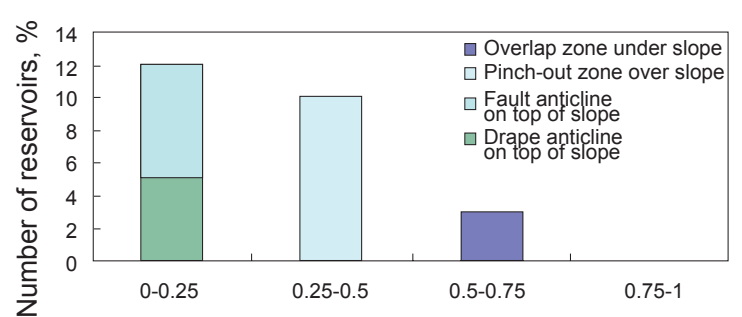

Distance from bottom to top of uplift after normalization

(a) Distribution of reservoir number in upper structural layers

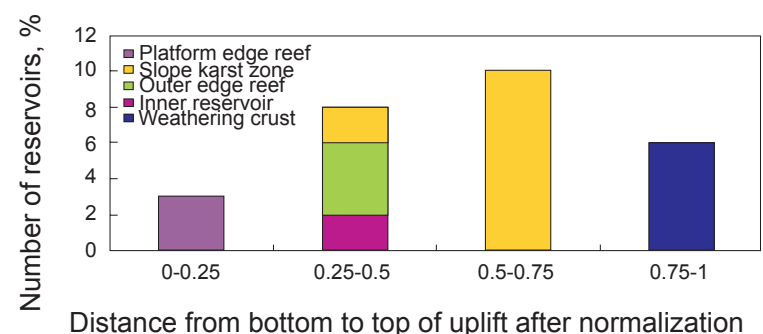

(c) Distribution of reservoir number in lower structural layers

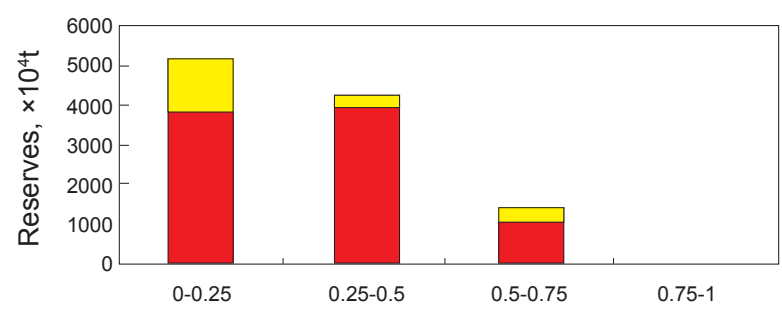

Distance from bottom to top of uplift after normalization

(b) Distribution of reserves in upper structural layers

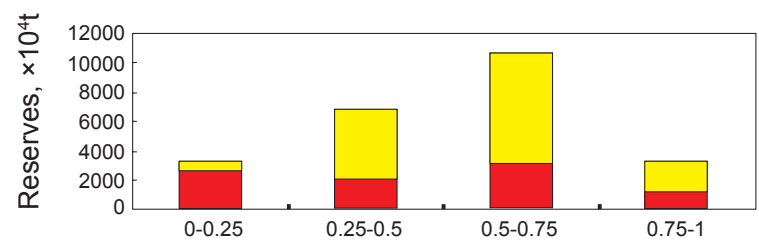

Distance from bottom to top of uplift after normalization

(d) Distribution of reserves in lower structural layers

Fig. 7 Distribution of hydrocarbon reservoirs in the upper and lower structural layers in the Tazhong Uplift

are formed on the slopes (e.g., the Tazhong83 condensate gas reservoir and the Tazhong16 Ordovician condensate gas reservoir), and reef flat reservoirs are formed at the foot of the slopes (e.g., the Tazhong No.1 condensate gas reservoir).

4) The geologic model of the Tazhong Palaeo-uplift controlling reservoirs can be summarized into eight types (Fig. 8). For the clastic rocks of upper structural layers, drape-anticline, fault-anticline, and fault-block reservoirs are developed in the top of the slopes, and pinch-out, overlap, and deep-water fan-like reservoirs are developed in the upper part, lower part and at the foot of the slopes respectively. For the carbonate rocks of lower structural layers, weathering crust reservoirs are developed in the top of the slopes, and reef flat reservoirs, karst belt reservoirs, and belt reservoirs are developed on the side margin of the palaeo-uplift, on the slopes and in the inner fractures respectively.

\subsection{Understanding that the effective regional caprock and reservoir-caprock combinations dominate the vertical distribution of hydrocarbon reservoirs}

The formation and distribution of regional caprocks determine the formation and distribution of large oil and gas fields (Zhou, 1997; Pang et al, 2007). The effective regional caprock refers to the caprock whose thickness is greater than fault displacement. The physical properties of the reservoir bed determine whether oil and gas can
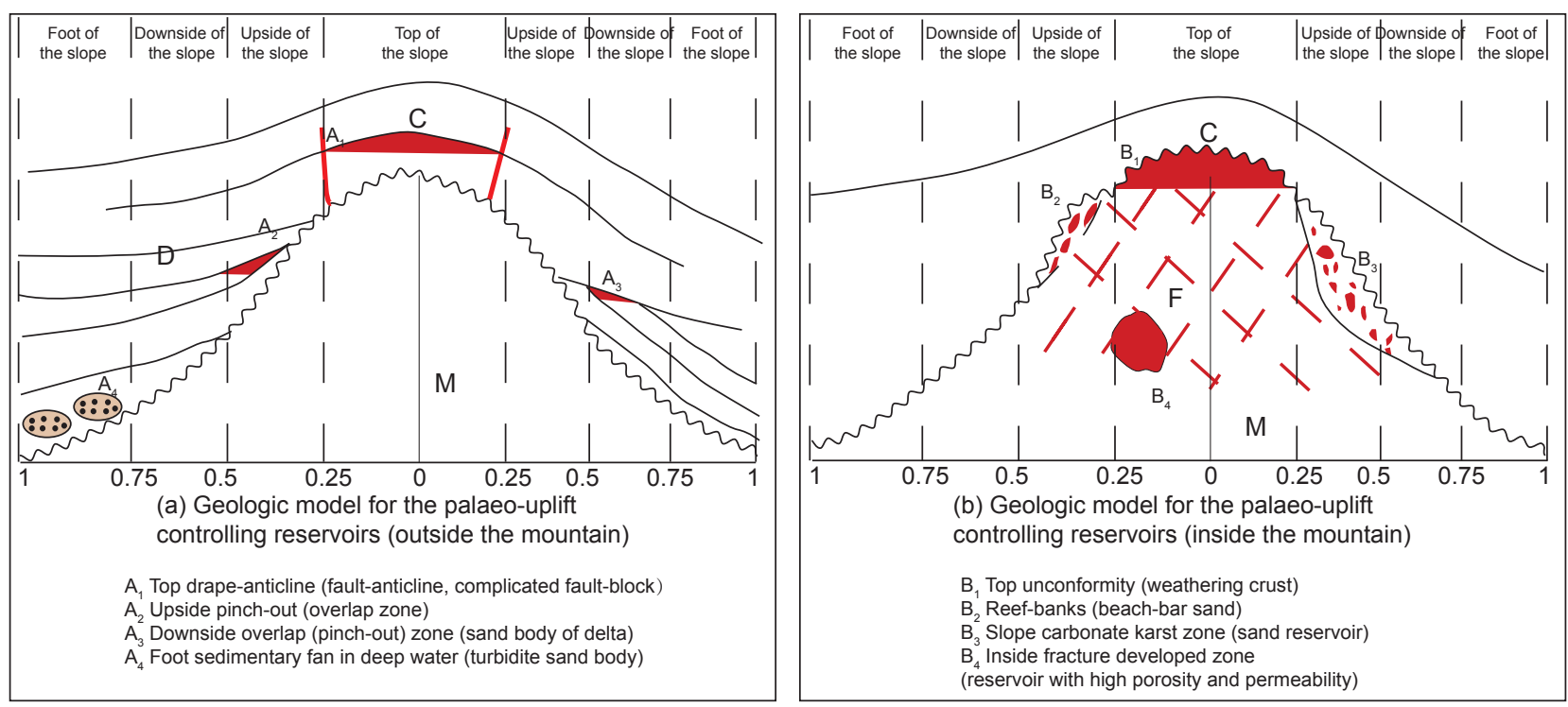

Fig. 8 Geologic models of the Tazhong Palaeo-uplift controlling reservoirs 
accumulate in reservoirs, the size of reservoirs, and the hydrocarbon properties in the trap (Zhang and Zhang, 1989). The reservoir-caprock combinations can determine the vertical distribution of hydrocarbon reservoirs. There are four sets of regional caprocks in the platform of the Tarim Basin, including the Carboniferous mudstone, the Silurian red mudstone, the Ordovician thick mudstone and the Cambrian gypsum salt. These regional caprocks determine the hydrocarbon migration and accumulation (Fig. 9). Various types of reservoir rocks and caprocks form eight sets of reservoir-caprock combinations, in which all the discovered oil and gas pools are located (Fig. 10). The largest reserves are found in the four reservoir-caprock combinations near three unconformity surfaces: the Donghe sandstone reservoir-caprock combination near the C/D unconformity with the oil equivalent of 130 million tons, the asphalt-sandstone reservoir-caprock combination and the Lianglitage combination near the $\mathrm{S} / \mathrm{O}$ unconformity with the oil equivalent of 30 million tons and 320 million tons respectively, and the Yingshan reservoir-caprock combination near the $\mathrm{O}_{3} / \mathrm{O}_{1}$ unconformity with the oil equivalent of 100 million tons.

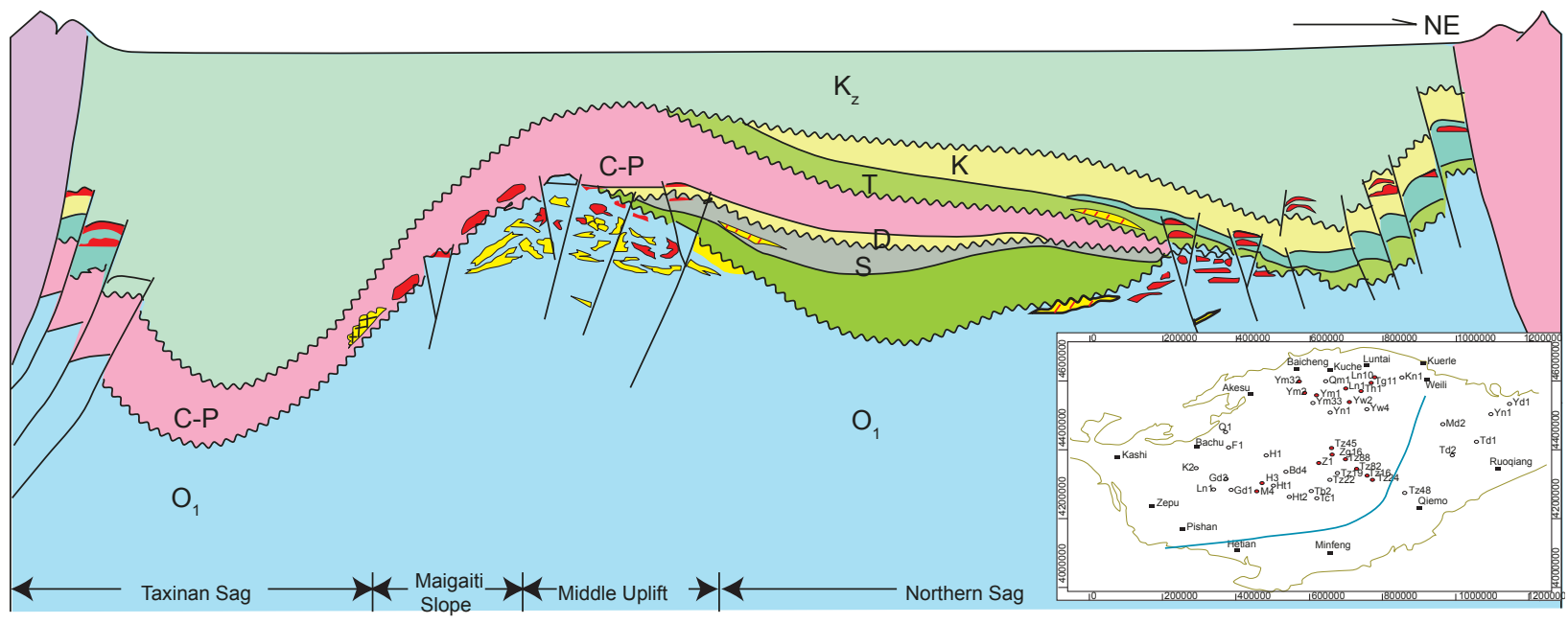

Fig. 9 Regional caprocks determine the vertical distribution of hydrocarbon reservoirs

\subsection{Understanding that structure balance belts influence the reconstruction and residual potential of reservoirs after accumulation}

The structure balance belt refers to a zone or belt that underwent few changes and remained relatively stable in the history of multiple structural transformations in a hydrocarbon-bearing basin. For the early formed reservoirs, the preservation conditions are of great importance because exposure of the reservoirs to the ground surface may cause damage to the oil and gas. Therefore, the structure balance belts on the slopes are favorable for hydrocarbon preservation. As to the reservoirs formed later, the structure balance belts are on the pathway of migration, thus are likely to capture and preserve oil and gas that pass through them. In other words, the structure balance belts, as the most favorable zones for capturing and preserving oil and gas, control the hydrocarbon potential after reservoir reconstruction (Zhou et al, 2004). In the early period, the Tazhong Palaeouplift was high in the west but low in the east. After largescale structural movements in the late Hercynian period, it became low in the west but high in the east, which has lasted until the present. The Tazhong62 and Tazhong1 well zones, located at the center of the palaeo-uplift, are in the structure balance belt, where most of the discovered hydrocarbons are distributed (Fig. 1, Fig. 11).

\subsection{Understanding the rules and mechanisms of fractures controlling oil and gas}

The control of fractures on oil and gas can be summarized into four aspects (Fig. 12)

1) As the main channels of vertical migration, fractures are the most effective pathways for oil and gas migration. Therefore, the distribution of oil and gas is often closely related to the layers cut by fractures ( $\mathrm{Fu}$ and $\mathrm{Fu}, 2001)$. The traps developed surrounding the fracture zones tend to be places for oil and gas accumulation. The reservoirs already discovered in the Tazhong area are mainly distributed along the Tazhong No.1 fracture zone, the Tazhong10 fracture zone and the Central Horst Belt (Fig. 3). With the fractures from north to south, the discovered reservoir beds are also from north to south. The fact that oil and gas accumulate where fractures are developed indicates that fractures control the formation and distribution of hydrocarbon reservoirs.

2) The crossing point of multiple faults is not only a point of oil and gas charging but also a mixing point of multisource oil and gas. The properties of hydrocarbon found in the same fault zone are similar, their biomarkers are comparable and the geochemical indicators change regularly outwards from the intersection point of faults. The cracking gas invasion occurred in the last hydrocarbon accumulation in the Yanshan period in the Tazhong area. The fault crossing point is the focus of gas charging, and the composition of natural gas changes regularly outwards from the intersection point.

3) The reservoirs around the fault zone have good oilbearing property. The study results show that the porosity and permeability around the fault zone are much better than those outside the fault zone, which indicates high oil and gas productivity. The productivity generally declines when the 


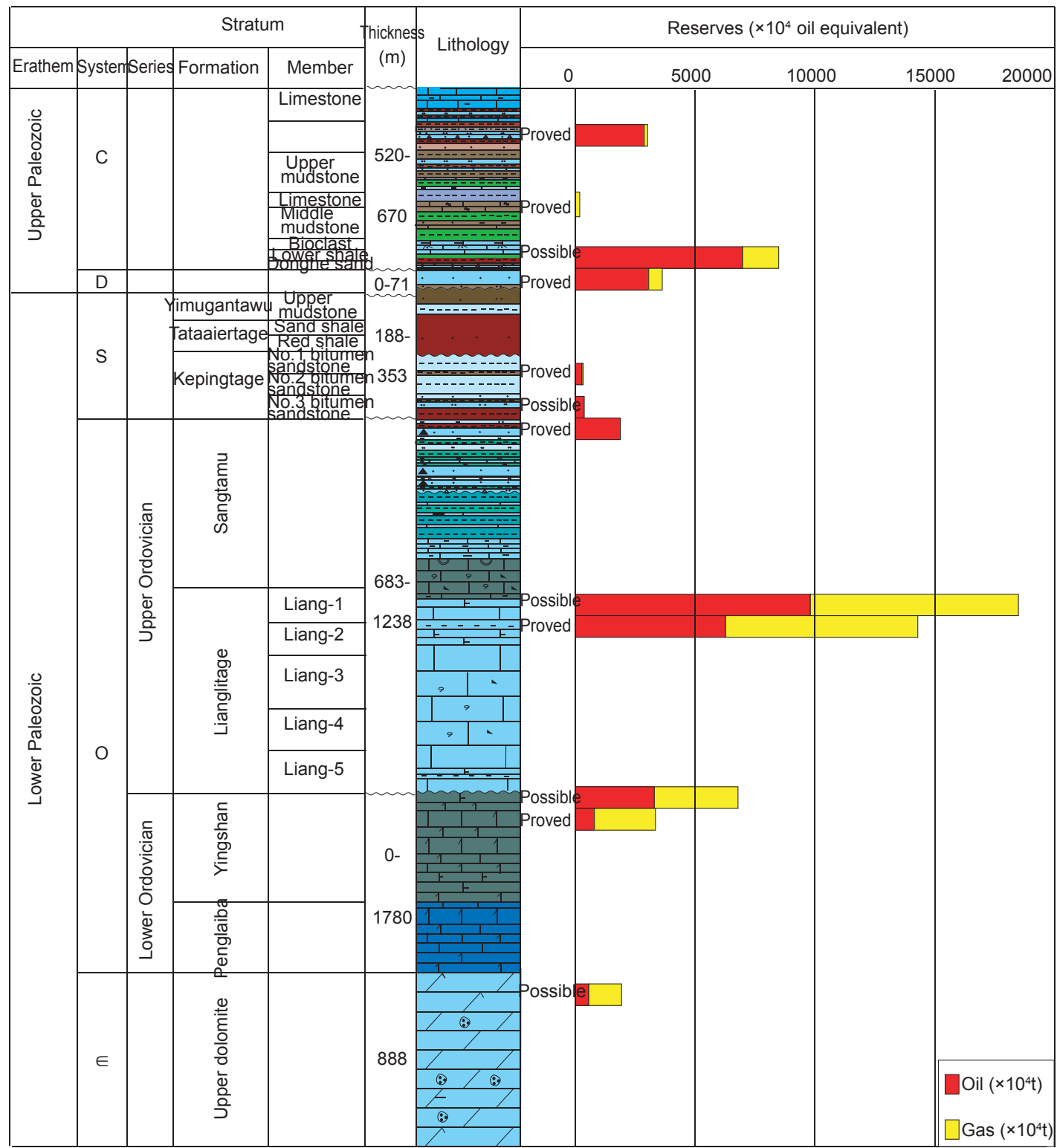

Fig. 10 Reservoir-caprock combinations and total reserves found in different combinations in the Tazhong area

well is $15 \mathrm{~km}$ away from the fault zone, which reflects the indirect control of fault on oil and gas distribution.

4) The direct control of faults on oil and gas distribution is expressed by the formation of fault reservoirs, which is the most general form in superimposed basins, and it has been discussed by many scholars (Pang et al, 2003; Hu et al, 2006; Yang et al, 2007b; Feng et al, 2008).

\subsection{Understanding the types of favorable reservoirs and their characteristics of controlling oil and gas distribution}

The favorable reservoirs in the Tazhong Uplift include reef and bank facies limestone, limestone cave carbonate, diagenetic crack dolomite and sandstone (Wei et al, 2000; Miao et al, 2007; Liu et al, 2008; Luo et al, 2008). The control on oil and gas distribution is mainly in two aspects.

1) The lithofacies control the distribution area of hydrocarbon reservoirs macroscopically
The carbonate hydrocarbon reservoirs in the Tazhong area are mainly distributed in the reef and bank depositional environments. From the viewpoint of lithology, they are mainly distributed in the biological framestone, algal clastic limestone, sand clastic limestone and bioclastic calcarenite. The sandstone reservoirs that have been found are mainly distributed in the siltstone and fine sandstone in foreshoreshoreface and tidal flat facies, accounting for $80 \%$ of the total oil and gas reservoirs. There are good relationships between the number and reserves of reservoirs and reservoir properties such as oil saturation (Fig. 13).

2) The porosity and permeability control the oil-bearing potential within hydrocarbon reservoirs

The statistical results show that the critical conditions of physical properties of clastic reservoirs decrease with increasing burial depth. The porosity in most hydrocarbon reservoirs ranges from $8 \%$ to $20 \%$ and the permeability ranges from $1 \mathrm{md}$ to $100 \mathrm{md}$. If the values of porosity and 


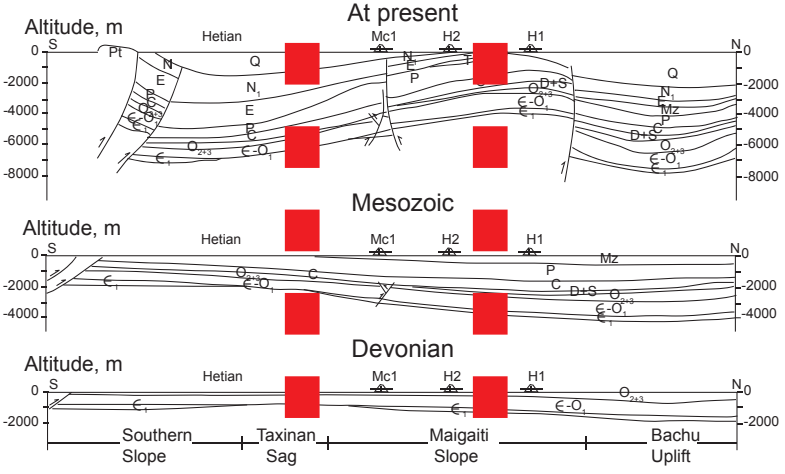

(a) An example for structural balance belt controlling the oil and gas distribution in eastern Taxinan Sag

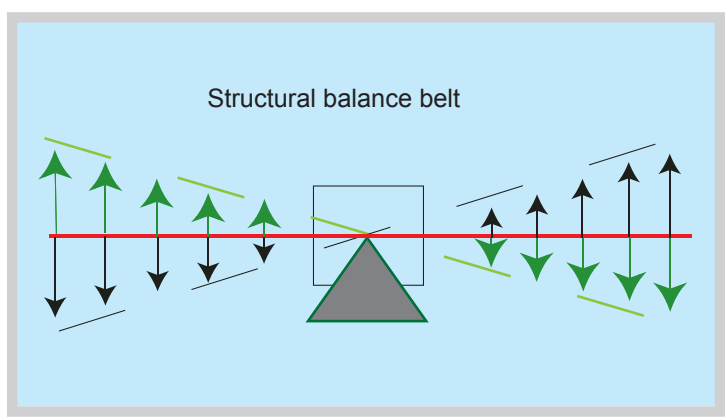

(c) Geological model of structural balance belt

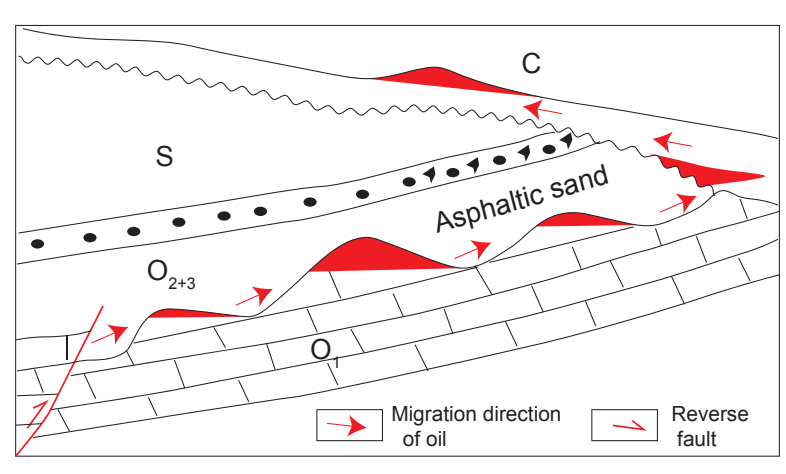

(b) An example for structural balance belt controlling the oil and gas distribution in Tazhong Uplift

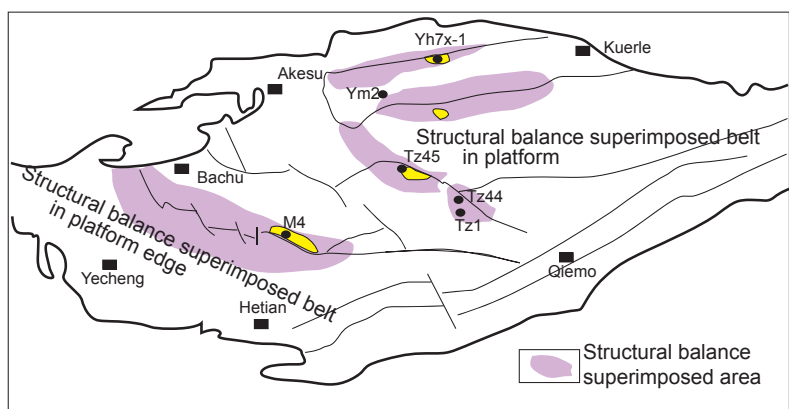

(d) Predicted favorable zones of oil and gas

Fig. 11 Control of structure balance belts on hydrocarbon accumulation in the Tazhong area (Zhou et al, 2004)

permeability are below a specific critical value (porosity $<8 \%$, permeability $<1 \mathrm{md}$ ), there will be no oil and gas reservoirs. The oil saturation and physical properties of reservoirs have shown a positive correlation, the higher the porosity and permeability, the higher the oil saturation. When the values of porosity and permeability are below a specific critical value (porosity $<8 \%$, permeability $<1 \mathrm{md}$ ), the value of oil saturation is smaller than $50 \%$ (Fig. 14).

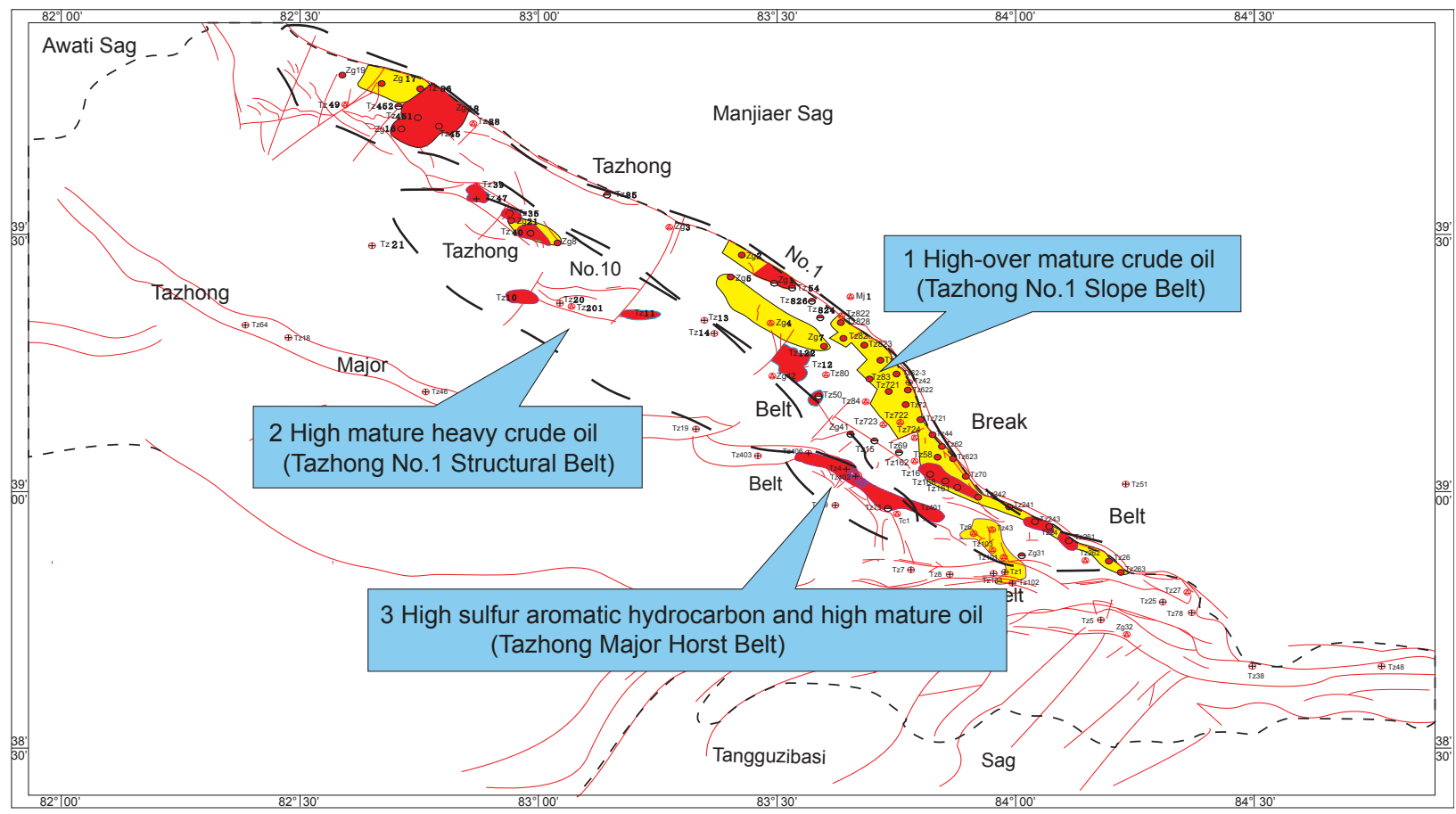

(a) Similar hydrocarbon properties in the same fault zone 

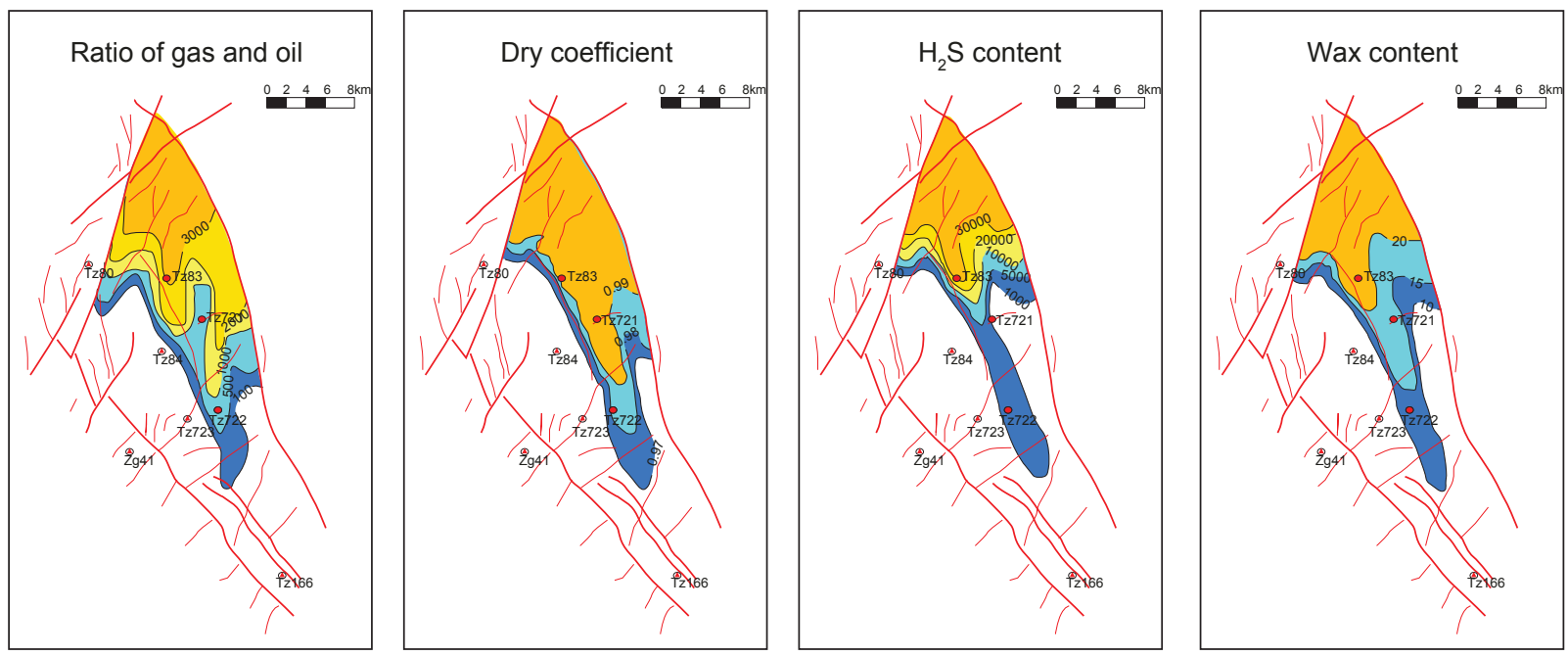

(b) Fault intersection zone is the favorable zone for oil and gas accumulation

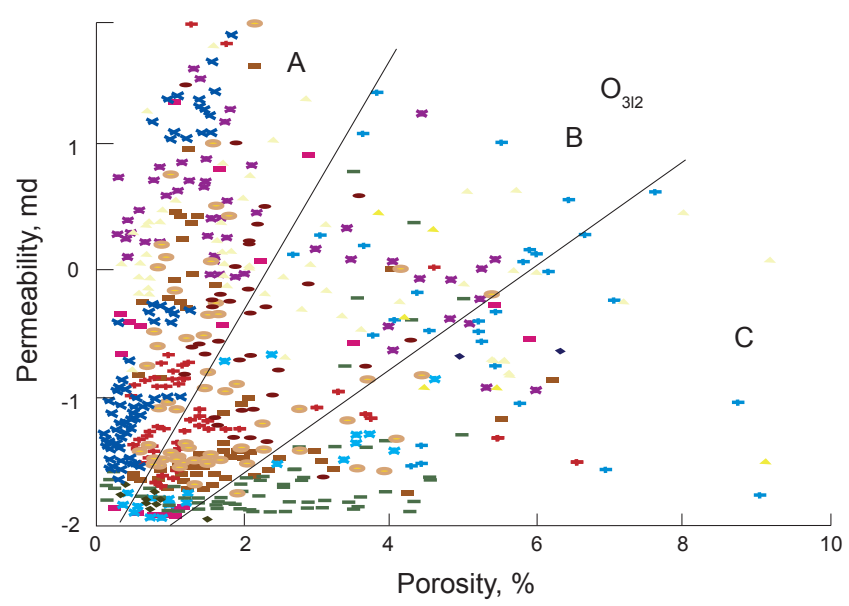

(c) Favorable crack reservoirs around the fault intersection zone
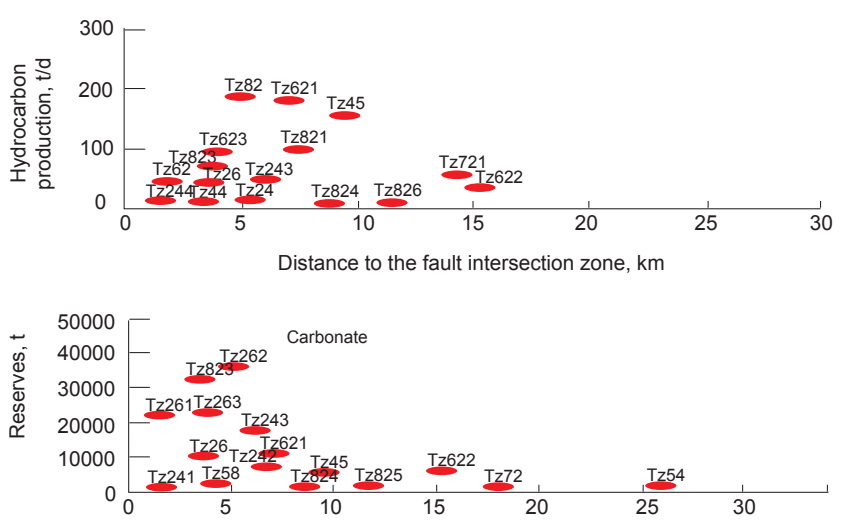

Distance to the fault intersection zone, $\mathrm{km}$

(d) High hydrocarbon production around the fault intersection zone

Fig. 12 Control of faults on hydrocarbon in the Tazhong Uplift

\section{Conclusions and proposal}

\subsection{Conclusions}

1) The reservoir distribution in the Tazhong area is characterized by "blocking in the east and west, gas in the north but oil in the south, and gas in the underlying layers but oil in the overlying layers".

2) There are four stages in the reservoir formation in the Tazhong area: the early Caledonian, the late Caledonian, the late Hercynian and the Yanshan-Himalayan.

3) The hydrocarbon in the Tazhong area mainly comes from mixed Cambrian and Ordovician sources, and the contribution of Cambrian source rocks is between $13 \%$ and $91 \%$. It is $100 \%$ only for individual reservoirs and decreases with increasing depth.

4) The favorable reservoirs in the Tazhong Uplift include reef and bank facies limestone, limestone cave carbonate, diagenetic crack dolomite and sandstone. The lithofacies control the distribution area of hydrocarbon reservoirs macroscopically, and the porosity and permeability control the oil-bearing potential within hydrocarbon reservoirs.

5) Eight sets of favorable reservoir-caprock combinations control the vertical distribution of hydrocarbon reservoirs. The largest reserves are found in the four reservoir-caprock combinations near three unconformity surfaces: the C/D reservoir-caprock combination, $\mathrm{S} / \mathrm{O}$ reservoir-caprock combination and the $\mathrm{O}_{3} / \mathrm{O}_{1}$ reservoir-caprock combination.

6) As an inherited palaeo-uplift, the Tazhong area serves as the most favorable area for hydrocarbon migration and accumulation. For the clastic rocks of upper structural layers (Carboniferous-Silurian), drape-anticlines are formed on the top, pinch-out reservoirs are formed on the slopes, and overlap reservoirs are formed in the lower parts of the western slopes. For the carbonate rocks (Ordovician-Cambrian), weathering crust reservoirs are formed on the top, karst oil reservoirs and inner-structural condensate gas reservoirs are formed on the slopes, and reef flat reservoirs are formed at the foot of the slopes.

7) The superimposition of relatively stable areas in the process of multiple tectonic events is favorable for 


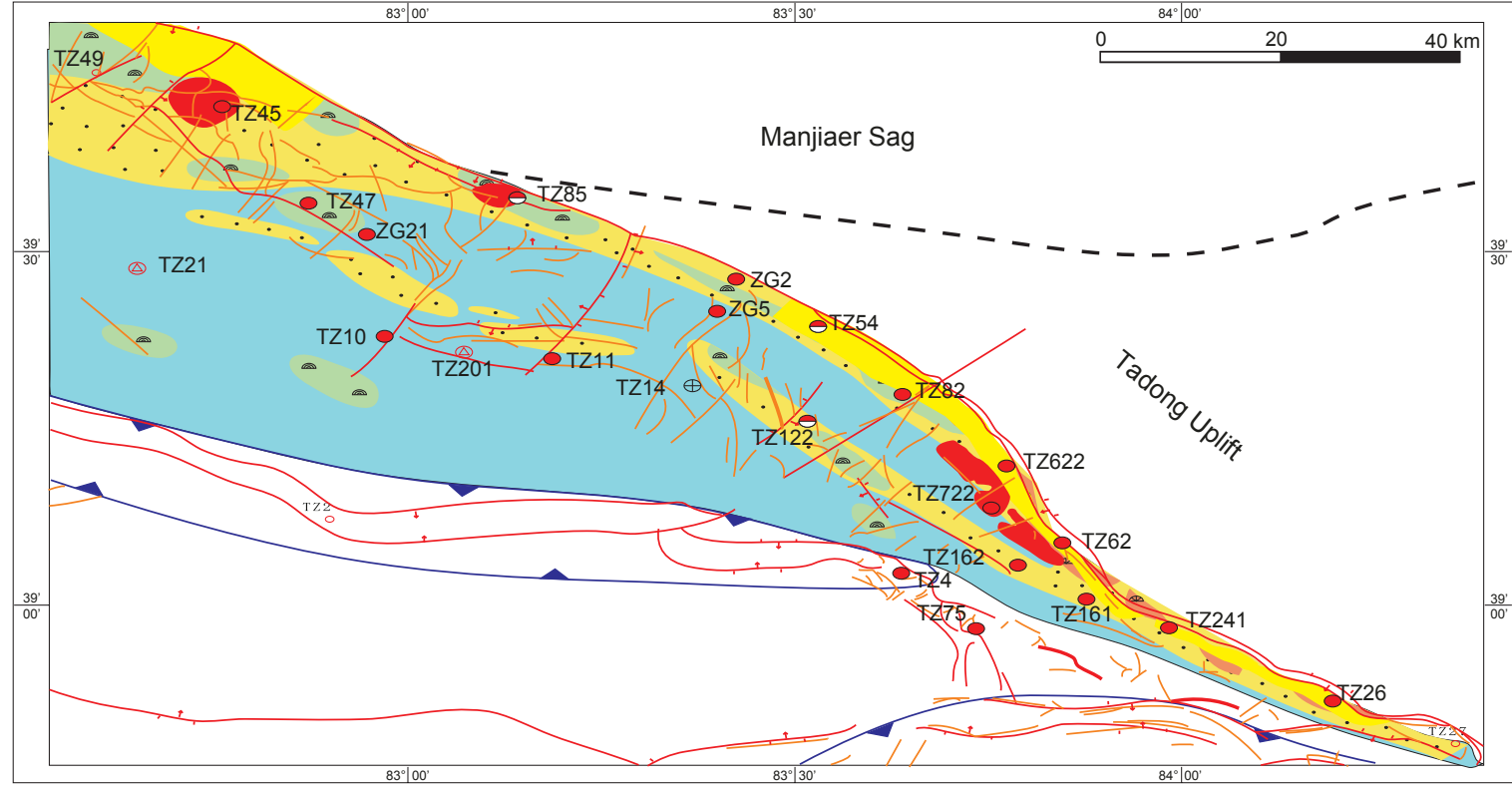

(a) The relationship between facies and hydrocarbon distribution

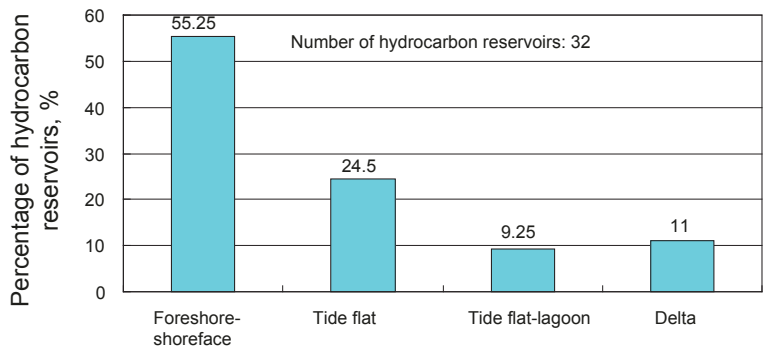

(b) The statistics of relationship between facies and hydrocarbon distribution in clastic reservoirs

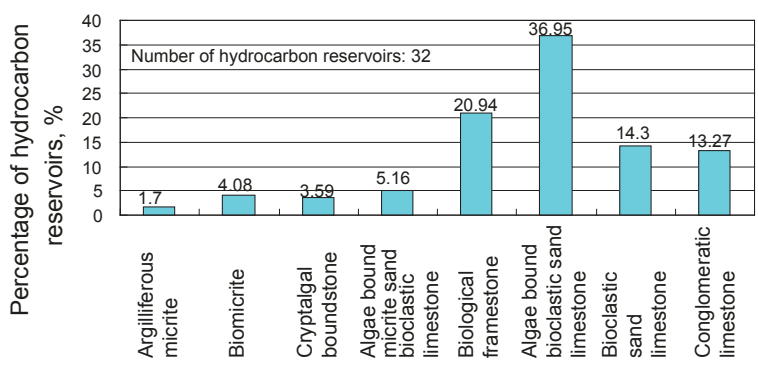

(c) The statistics of relationship between facies and hydrocarbon distribution in carbonate reservoirs

Fig. 13 Relationship between lithofacies and oil and gas distribution in the Tazhong area
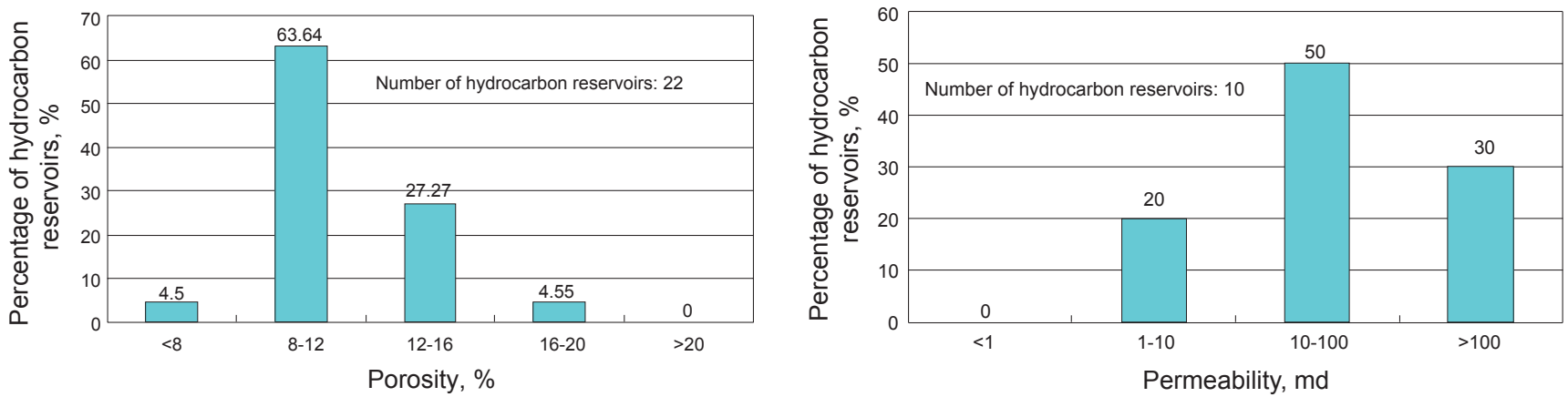

(a) Relationship between physical properties and distribution of reservoirs in clastic rocks
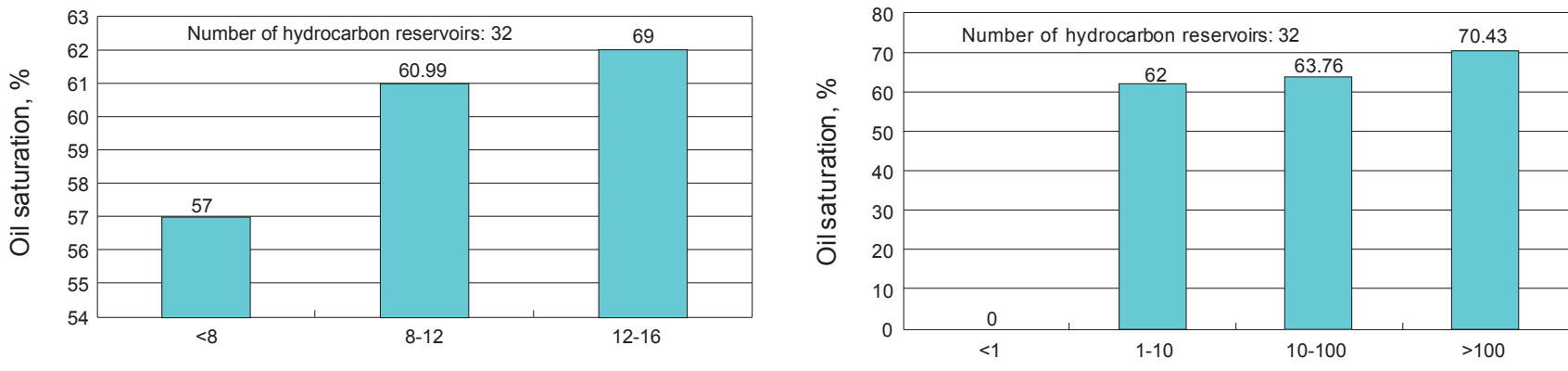

Porosity, \%

Permeability, md

(b) Relationship between physical properties and oil saturation in carbonate rocks

Fig. 14 Relationship between physical properties of reservoirs and oil and gas distribution in the Tazhong area 
hydrocarbon accumulation and preservation, while the superimposition of relatively unstable areas is not favorable for hydrocarbon accumulation and preservation.

8) Faults control the hydrocarbon formation and distribution in the Tazhong area. Faults, as a part of the petroleum transportation system, control the layers and traps to which hydrocarbon migrates. The crossing point of multiple faults is not only a focus of oil and gas charging but also a mixing point of multi-source oil and gas, which controls the composition change and differentiation of hydrocarbon. Faults control the development of cracks nearby and the distribution and oil-bearing property of favorable reservoirs. It is easy to form fault block reservoirs through faults blocking oil and gas migration.

\subsection{Proposal}

1) We clarified the main controlling factors of hydrocarbon accumulation in the Tazhong area, but the accumulated and destroyed amount and residual potential of hydrocarbon in the process of hydrocarbon accumulation, adjustment and reconstruction are still not discussed. It is of great significance to study the amounts of hydrocarbon generation, expulsion, loss (include destroyed hydrocarbon) and ultimate remaining accumulation, which can guide the exploration direction and potential.

2) We discussed the differences in controlling hydrocarbon distribution between upper and lower structural layers. However, the differences of hydrocarbon accumulation between carbonate and clastic rocks are still not discussed. It is important to study the differences of hydrocarbon accumulation mechanisms between carbonate and clastic rocks.

3) We discussed the control of palaeo-uplift on the formation of different types of hydrocarbon reservoirs. However, the differences of oil-bearing potential among different types of traps are still not discussed. It is of great significance to study the differences of oil-bearing potential among different traps, make clear the main controlling factors, build the quantitative model, and quantitatively predict the oil-bearing potential for evaluating and optimizing the most favorable exploration targets.

\section{Acknowledgements}

This work is supported by the National Basic Research Program of China (973 Program, Grant No. 2006CB202308).

\section{References}

Cai C F, Hu W S and Worden R H. Thermochemical sulphate reduction in Cambro-Ordovician carbonates in central Tarim. Marine and Petroleum Geology. 2001. 18(6): 729-741

Cai C F, Li K K, Ma A L, et al. Distinguishing Cambrian from Upper Ordovician source rocks: Evidence from sulfur isotopes and biomarkers in the Tarim Basin. Organic Geochemisty. 2009. 40(7): 755-768

Cai C F, Wu G H, Li K K, et al. Thermochemical sulfate reduction and origin of sulfur in crude oils in Palaeozoic carbonates. Bulletin of Mineralogy, Petrology and Geochemistry. 2007. 26(1): 44-48 (in Chinese)
Chen J F, Xu Y C and Huang D F. Geochemical characteristics and origin of natural gas in Tarim Basin, China. AAPG Bulletin. 2000. 84(5): 591-606

Feng J W, Dai J S and Ge S Q. Structural evolution and pool-forming in the Wuxia fault belt of the Junggar Basin. Journal of China University of Petroleum. 2008. 32(3): 23-29 (in Chinese)

$\mathrm{Fu} \mathrm{G}$ and Fu X F. Controlling of fault transport system and its combination to the formation and distribution of oil or gas reservoirs. Global Geology. 2001. 20(4): 345-350 (in Chinese)

Han J F, Mei L F, Yang H J, et al. The study of hydrocarbon origin, transport and accumulation in the Tazhong area, Tarim Basin. Natural Gas Geoscience. 2007. 18(3): 426-434 (in Chinese)

Hanson A D, Zhang S C, Moldowan J M, et al. Molecular organic geochemistry of the Tarim Basin, northwest China. AAPG Bulletin. 2000. 84(8): 1109-1128

He D F. Oil and gas geology theory and practice in cratonic basins. China Petroleum Exploration. 1996. 1(1): 18-25 (in Chinese)

Hu S Y, Yu Y J, Dong D Z, et al. Control of fault activity on hydrocarbon accumulation in the central Junggar Basin. Acta Petrolei Sinica. 2006. 27(1): 1-7 (in Chinese)

Jia C Z, Yao H J, Wei G Q, et al. Structural Evolution and Regional Structural Geology in the Tarim Basin. Beijing: Petroleum Industry Press. 1995. 130-135 (in Chinese)

Kang Y Z. Collected Works of Petroleum Geology in the Tarim Basin of China. Beijing: Geology Press. 1996. 114-123 (in Chinese)

Kang Y Z. Discussion of the geologic conditions of the formation of large oil and gas fields in the Tarim Basin. Geoscience. 1992. 6(1): 39-45 (in Chinese)

Kang Z H, Wei L L and Kang Y F. Analysis of the formation stages of oil and gas reservoirs in the Tarim Basin. Xinjiang Petroleum Geology. 2001. 22(6): 462-464 (in Chinese)

Li S M, Pang X Q, Yang H J, et al. Characteristics and genetic type of the oils in the Tazhong Uplift. Earth Science-Journal of China University of Geosciences. 2008. 33(5): 635-642 (in Chinese)

Li X D. Formation and evolution of Lower Palaeozoic petroleum systems in the Manjiaer depression of the Tarim Basin. In: Application and Advancements of Chinese Petroleum Systems. Beijing: Petroleum Industry Press. 1997. 102-108 (in Chinese)

Li Y P, Wang Y, Sun Y S, et al. Two accumulation stages of the Silurian hydrocarbon reservoirs in the central area of the Tarim Basin. Chinese Journal of Geology. 2002. 37(supplement): 45-50 (in Chinese)

Liang D G, Zhang S C, Zhang B M, et al. Understanding on marine oil generation in China based on the Tarim Basin. Earth Science Frontiers. 2000. 7(4): 534-546 (in Chinese)

Liu L F and Kang Y S. Study on secondary migration of hydrocarbons in the Tazhong area of the Tarim Basin in terms of carbazole compounds. Chinese Journal of Geochemistry (English Edition). 1999. 18(2): 97-103

Liu L F, Li Y, Wang P, et al. Reservoir types and favorable oil-gas exploration zone prediction of the Upper Ordovician Lianglitage Formation in the Tazhong No.1 fault belt of the Tarim Basin. Journal of Palaeogeography. 2008. 10(3): 221-230 (in Chinese)

Luo P, Zhang J, Liu W, et al. Characteristics of marine carbonate hydrocarbon reservoirs in China. Earth Science Frontiers. 2008. 15(1): 36-49 (in Chinese)

Lü X X, Yang H J, Yang N, et al. Further recognition of petroleum exploration potential of marine carbonates in the western Tarim Basin. Petroleum Science. 2007. 4(3): 21-25

Miao J J, Jia C Z, Zou C N, et al. Characteristics and exploration fields of paleo-karst reservoirs at the top of the early Ordovician in the central Tarim Uplift. Natural Gas Geoscience. 2007. 18(4): 496-500 (in Chinese)

Pan C C and Liu D Y. Molecular correlation of free oil, adsorbed oil and inclusion oil of reservoir rocks in the Tazhong Uplift of the Tarim 
Basin, China. Organic Geochemisty. 2009. 40(3): 387-399

Pang X Q, Gao J B and Meng Q Y. A discussion on the relationship between tectonization and hydrocarbon accumulation and dissipation in the platform-basin transitional area of the Tarim Basin. Oil \& Gas Geology. 2006. 27(5): 594-603 (in Chinese)

Pang X Q, Luo Q, Jiang Z X, et al. Accumulating diversity and its mechanism between hanging and lower walls of faults in superimposed basins. Chinese Journal of Geology. 2003. 38(3): 297306 (in Chinese)

Pang X Q, Luo X R, Jiang Z X, et al. Advancements and problems on hydrocarbon accumulation research of complicated superimposed basins in western China. Advances in Earth Sciences. 2007. 22(9): 879-885 (in Chinese)

Wang J Q. Oil active history in the Tarim Basin. In: Collected Works of Petroleum Geology in the Tarim Basin of China. Beijing: Geology Press. 1996. 132-140 (in Chinese)

Wang Z C and Zhao W Z. A role of marine paleo-uplift in reservoirforming of oil and gas. China Petroleum Exploration. 2006. 11(4): 26-34 (in Chinese)

Wei G Q, Jia C Z, Song H Z, et al. Ordovician structural-depositional model and prediction for profitable crack reservoir of carbonate rock in the Tazhong area, Tarim Basin. Acta Sedimentologica Sinica. 2000. 18(3): 408-412 (in Chinese)

Wu M B, Wang X M, Chen Q L, et al. Achievements from petroleum exploration in the central Tarim area and its further exploratory directions. Xinjiang Petroleum Geology. 2002. 23(2): 95-98 (in Chinese)

Yang H J, Han J F, Chen L X, et al. Characteristics and patterns of complex hydrocarbon accumulation in the Lower Paleozoic carbonate rocks of the Tazhong Palaeo-uplift. Oil \& Gas Geology. 2007a. 28(6): 784-790 (in Chinese)

Yang H J, Hao F, Han J F, et al. Fault systems and multiple oil-gas accumulation play of the Lunnan lower uplift, Tarim Basin. Chinese Journal of Geology. 2007b. 42(4): 795-811 (in Chinese)

Yang $\mathrm{H} \mathrm{J}, \mathrm{Wu} \mathrm{G} \mathrm{H}$, Han J F, et al. Characteristics of hydrocarbon enrichment along the Ordovician carbonate platform margin in the central uplift of the Tarim Basin. Acta Petrolei Sinica. 2007c. 28(4) 26-30 (in Chinese)

Yang H J, Wu G H, Sun L X, et al. Condition and explorative direction of lithologic reservoir of Silurian in northern slope of the Tazhong Uplift. Xinjiang Petroleum Geology. 2007d. 28(3): 286-288 (in Chinese)
Zhai G M and He W Y. An important petroleum exploration region in the Tarim Basin. Acta Petrolei Sinica. 2004. 25(1): 1-7 (in Chinese)

Zhai G M and Wang J J. Analysis of petroleum geology in the Tazhong region. Acta Petrolei Sinica. 1999. 20(4): 1-7 (in Chinese)

Zhang G Y, Wang H J, Song J G, et al. The identification of the Manxi Cambrian-Lower Ordovician petroleum system of the Tarim Basin and its application to oil and gas exploration. China Petroleum Exploration. 2002. 7(4): 18-24 (in Chinese)

Zhang H F and Zhang W X. Petroleum Geology. Beijing: Petroleum Industry Press. 1989 (in Chinese)

Zhang S C, Hanson A D, Moldowan J M, et al. Paleozoic oil-source rock correlations in the Tarim Basin, NW China. Organic Geochemistry. 2000a. 31(4): 273-286

Zhang S C, Zhang B M, Wang F Y, et al. Middle-upper Ordovician formation: the main source rocks in the Tarim Basin. Marine Origin Petroleum Geology. 2000b. 5(2): 16-22 (in Chinese)

Zhao J Z and Li Q M. The hydrocarbon accumulation stages and history of marine hydrocarbon in the craton area of the Tarim Basin. Chinese Science Bulletin. 2002. 47(S1): 116-121 (in Chinese)

Zhou X J, Fan M and Qiu Y Y. On characters of oil/gas and poolforming models in the middle Tarim Basin. Experimental Petroleum Geology. 1997. 19(2): 148-152 (in Chinese)

Zhou X X. Essentials about hydrocarbon distribution controlled by source and seal. Petroleum Exploration and Development. 1997. 24(6): 4-7 (in Chinese)

Zhou X X. The petroleum reservoir forming characteristics of the composite superimposed basin - an example from the Tarim Basin. Earth Science Frontiers. 2000. 7(3): 39-47 (in Chinese)

Zhou X Y, Lü X X, Jin Z J, et al. Accumulation of petroleum in the carbonate rocks in the pivot positions of structural activities in the Tarim Basin. Journal of Xi' an Shiyou University (Natural Science Edition). 2004. 19(4): 19-25 (in Chinese)

Zhou X Y, Wang Z M, Yang H J, et al. Cases of discovery and exploration of marine fields in China (Part 5): The Tazhong Ordovician condensate field in the Tarim Basin. Marine Origin Petroleum Geology. 2006. 11(1): 45-52 (in Chinese)

Zhou X Y, Yang H J, Wu G H, et al. The experiences and targets for exploration of large oil-gas field in the Tazhong area, Tarim Basin. Xinjiang Petroleum Geology. 2009. 30(2): 149-151 (in Chinese) 